\title{
Late Holocene Aleppo pine (Pinus halepensis Miller) woodlands in Mallorca (Balearic Islands, Western Mediterranean): Investigation of their distribution and the role of human management based on anthracological, dendro-anthracological and archaeopalynological data
}

\author{
Llorenç Picornell-Gelabert ${ }^{\mathrm{a}, *}$, Gabriel Servera-Vives ${ }^{\mathrm{a}}$, Yolanda Carrión Marco ${ }^{\mathrm{b}}$, \\ Francesc Burjachs ${ }^{c, d, e}$, Andrés Currás ${ }^{\mathrm{f}}$, Yolanda Llergo ${ }^{\mathrm{g}}$, Alexa Dufraisse ${ }^{\mathrm{h}}$, \\ Martín De Luís Arrillaga ${ }^{i}$, Maurici Mus Amézquita ${ }^{j}$

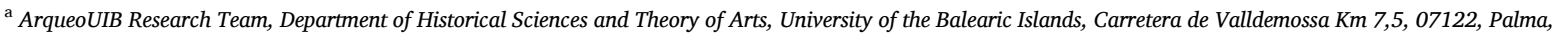 \\ Mallorca, Spain \\ ${ }^{\mathrm{b}}$ PREMEDOC- GIUV2015-213. Universitat de València, Departament de Prehistòria, Arqueologia i Història Antiga, Av. Blasco Ibañez 28, 46010 València, Spain \\ ${ }^{\mathrm{c}}$ ICREA, Pg. Lluís Companys 23, 08010 Barcelona, Spain \\ ${ }^{\mathrm{d}}$ Institut Català de Paleoecologia Humana i Evolució Social (IPHES), Zona Educacional 4, Campus Sescelades URV (Edifici W3), 43007 Tarragona, Spain \\ ${ }^{\mathrm{e}}$ Universitat Rovira i Virgili, Departament d'Història i Història de l'Art, Avinguda de Catalunya 35, 43002 Tarragona, Spain \\ ${ }^{\mathrm{f}}$ Institute of Heritage Sciences (Incipit), Spanish National Research Council (CSIC), Av. de Vigo s/n 15705 Santiago de Compostela, Spain \\ ${ }^{\mathrm{g}}$ Department of History and Archaeology, Seminar of Prehistoric Studies and Research, Universitat de Barcelona, Montalegre 6, E-08001, Barcelona, Spain \\ ${ }^{\mathrm{h}}$ CNRS/MNHN, UMR 7209 Archéozoologie, Archéobotanique: Sociétés, Pratiques et Environnements, Sorbonne Université, CP56, 55 rue Buffon, 75005 Paris, France

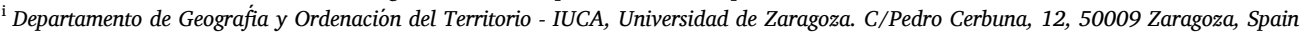 \\ ${ }^{\mathrm{j}}$ Department of Biology. University of the Balearic Islands, Carretera de Valldemossa Km 7,5, 07122, Palma, Mallorca, Spain
}

\section{A R T I C L E I N F O}

\section{Keywords:}

Aleppo pine (Pinus halepensis Miller)

Anthracology

Anthraco-typology

Archaeopalynology

Mallorca (Balearic islands)

\begin{abstract}
A B S T R A C T
The pioneering nature of Mediterranean pines and their phytosociological role have been largely discussed in relation to different agents (e.g., edaphic, climatic or anthropogenic). In this context, Aleppo pine is one of the most widespread pine species in the Mediterranean basin, as it is especially adapted to climatic constraints, such as drought and high seasonality, and has a high tolerance for salinity and strong coastal winds. It is also well adapted to regeneration after anthropogenic landscape disturbances, highlighting its important after-fire regeneration rates. In this sense, phytosociological studies conducted in Mediterranean landscapes have found that this species' wide distribution is mostly due to its rapid regeneration after human landscape transformation, including fire, and the abandonment of agricultural lands. Aleppo pine is considered to broadly develop after human action in sclerophyllous formation, in which it would be scarce or absent without human intervention. Parallel, paleoenvironmental and archaeobotanical studies have attempted to trace these trends back to prehistoric times to investigate this species' role in Late Pleistocene and Holocene vegetation and evaluate the role of climate and human action in its diachronic dynamics. In this study, we present a compendium of anthracological, dendro-anthracological and archaeopalyonological data with the objective of (i) investigating the nature and distribution of Aleppo pine on the island of Mallorca and (ii) evaluating the possibility that human action could have resulted in the spread of this pine species during the first two millennia of permanent human occupation of the island (c. 2300 cal. BCE-1st-century ACE). Investigating these archaeobotanical datasets, as well as making comparisons with anthracological and paleoenvironmental studies in neighbouring Mediterranean zones (Iberia), allowed us to attest that Aleppo pine is a natural, pre-human component of the Holocene vegetation of the island, and it is especially well-adapted to coastal environments. Moreover, we describe the trends and characteristics of the human management of pine woodlands through anthracology and dendroanthracology, suggesting that human action did not provoke widespread growth of Aleppo pine in Mallorca at the expense of other vegetation types during prehistory. Such processes, well-documented by current phytosociological studies, probably began at some unknown point after the Romanisation of the island.
\end{abstract}

\footnotetext{
* Corresponding author.

E-mail address: tokelau24@gmail.com (L. Picornell-Gelabert).
} 


\section{Introduction}

The nature and phytosociological role of Mediterranean pines have been largely discussed in the botanical and paleobotanical literature. Mediterranean pines are especially adapted to post-fire regeneration and are important pioneering trees in forest regeneration processes after human disturbances. In the specific case of Aleppo pine, one of the most widespread Mediterranean conifers, serotony and early flowering are considered adaptive traits favouring survival after crown fires, even if the pine does not survive the fire itself (Tapias et al., 2004; Daskalakou and Thanos 1996; Thanos and Daskalakou 2000; Ne' eman et al., 2004; Ne' eman and Izhaki, 2006; Pausas et al., 2004). This has been a relevant element in considering Aleppo pine a pioneer and invasive tree in Mediterranean environments (Pausas et al., 2002), often relating it to stages of the succession and environmental degradation of broadleaved forests formations (Bellot 1978; Peinado and Rivas-Martínez 1987).

In Mallorca, Aleppo pine woodlands represent the most widespread forest formations (IFN 2012) and have experienced a major increase since the mid-twentieth century, clearly favoured by changes in land use following abandoned agricultural lands and after fires (Berbiela 2015). In parallel, a negative social perception of this species has been increasing among the Balearic society, where, in many cases, it is considered an invasive tree brought by humans rather than via natural processes in the archipelago. It is also often considered fire-promoting and responsible for many plagues (Sureda-Negre et al., 2011).

However, recent research on Aleppo pine has noted that its adaptive and reproductive strategy, with partial serotony and quick initial growth, is relevant to competing where there are frequent fires and other edaphic and climatic constraints of the Mediterranean climate, especially drought (Martínez del Castilo et al., 2018; Ne' eman et al., 2004). Furthermore, the paleoenvironmental literature has also indicated that the post-fire regeneration and colonisation of degraded lands after human action are not the only potential explanations for the presence and development of pines in Mediterranean environments (Carrión et al., 2010; Carrión and Fernández 2009), at least not until more recent historical times (Aranbarri et al., 2020). Pines could have constituted the climax vegetation in areas where arid conditions would not have allowed the development of other types of forests (Badal, 2013).

Regarding such current discussions on the phytoecological role of Aleppo pine and the impact of anthropogenic landscape management on its diachronic dynamics, in this article, we aim to (i) define the use of pinewood by prehistoric societies on the island of Mallorca during the first two millennia of permanent human occupation of all the biotopes of the island (c. 2300 cal. BCE-1st-century ACE) and (ii) investigate the nature of Aleppo pine woodlands on the island, assessing the role of anthropogenic landscape management in this species' distribution during the studied period, aided by the knowledge of its actual ecological and distributional characteristics. We approach these objectives using a multi-proxy strategy, combining different kinds of archaeobotanical data (i.e., anthracology, dendro-anthracology and archaeopalynology) and discussing them in relation to paleoenvironmental sequences and the dynamics of Aleppo pine in neighbouring continental areas (Iberia).

\section{Archaeological and environmental setting}

Mallorca is the largest island of the Balearic archipelago, with a total surface of $3.620 \mathrm{Km}^{2}$. The geology of the island is almost exclusively calcareous, with only some non-calcareous substratum (i.e., Palaeozoic and Triassic) in the northern mountain range (Rosselló et al., 2003). There are no permanent watercourses on the island; its hydrographic network is composed of streams with intermittent water flows, mainly during spring and autumn, when the most significant precipitation occurs. There exist a number of shallow brackish lagoons along the coastline of the island that allow the development of particular types of vegetation in the wetlands.

The vegetation of the island is typically termo- and meso-
Mediterranean, characterised by an important development of macchia and scrublands. Woodlands are characterised by two main species: Pinus halepensis Miller and Quercus ilex L. (Llorens et al., 2007). The island is divided into three hydrographic and biogeographical regions: the Tramuntana mountain range, the largest mountains with some of the highest elevations of the archipelago (i.e., the maximum elevation at Son Torrella is 1445 m.a.s.l.), the Pla, the central plain, and the Llevant region along the southeastern coast (Rosselló et al., 2003).

\subsection{Current distribution of Pinus halepensis Miller in Mallorca}

Aleppo pine is a dominant species of Mallorcan tree-covered natural communities, except for oak forests (Quercus ilex L.), riversides of freshwater streams, rocky areas, and cliffs of the highest mountains. Currently, the island has 150,248.82 ha of forested lands (IFN 2012), with Aleppo pine present in more than 50\% of them (Berbiela 2015). The abundance of this species is attributed to its high ecological plasticity, as well as its rapid and robust regeneration in burned and unburned environments, partially due to the serotinous character of its cones (Goubitz et al., 2003). Moreover, human modifications of the landscape over the centuries have also been considered a key factor in the current distribution of Aleppo pine woodlands in Mallorca (Bolòs 1993; Gil et al., 2003).

Aleppo pine occupies most of the areas suitable for the development of sclerophyllous vegetal formations, where it would probably be scarce or rare, assuming that human action has favoured its spread. This is why all phytosociological researchers agree on considering Aleppo pine merely an accompanying species for sclerophyllous and pioneering formations. A characteristic phytoecological role is only conferred to Aleppo pine in some permanent littoral habitats, where it broadly develops due to its high tolerance to salinity and strong coastal winds (Bolòs 1996; Rivas-Martínez et al., 1992; Llorens et al., 2007).

The formation and overall abundance of long-resting extensive masses of secondary pine forests are interpreted as a general characteristic of Mallorcan vegetation and a direct consequence of anthropic disturbance and fire regimes (Llorens et al., 2007). Aleppo pine woodlands on marginal and non-cultivated areas of the island have been subject to secular exploitation. Moreover, extensive pine plantations were established in different areas of Spain after the Civil War (1936-1939) and planted in Mallorca primarily on sclerophyllous macchia (Gil et al., 2003). Land-use changes since the second half of the 20th century, characterised by a progressive abandonment of cultivated lands due to the redirection of the Balearic economy towards mass tourism and abandonment of the primary sector, has resulted in a notable increase in Aleppo pine forests, which have colonised abandoned cultivated lands to the point that they represent more than half of the current forested area of the island (Berbiela 2015).

\subsection{Holocene vegetation dynamics in the Balearic archipelago}

Several paleoenvironmental studies involving radiocarbon dating have been conducted on the Balearic Islands since the 1990s (e.g., Burjachs et al., 1994; Yll et al., 1997; 1999; Pérez-Obiol et al., 2000; Servera-Vives et al., 2018; Kaniewski et al., 2020). This research was performed on sedimentary records of littoral sequences focused on the Holocene, mainly from Menorca, while paleoenvironmental studies on Mallorca and Pitiuses remain scarce. At this time, there are only two published palynological studies conducted on Mallorca with reliable chronological and analytical resolution; both in the same wetland, s'Albufera d'Alcúdia (Burjachs et al. 1994, 1997, 2017).

KF14, a hemipelagic marine core, has revealed the vegetation dynamics from the upper Pleistocene to the Holocene (Yll et al., 1999; Roure et al., 1995; Pérez-Obiol et al., 2000). Pollen analysis of marine records allows researchers to trace regional climate and vegetation trends over time, while terrestrial records are more prone to recording micro-regional variability related to human-climate-environmental 
interactions (Mercuri et al., 2012). In this sense, the KF14 sequence has revealed pre-Holocene high values of Pinus and steppe taxa, such as Artemisia, along the sequence. This vegetation configuration characteristic of cold periods decreased during the interglacials/interstadials, where some temperate taxa, such as Corylus, Betula and deciduous Quercus, spread.

The Early Holocene implies a retreat of pine formations and the expansion of littoral communities of Juniperus and Ephedra and some mesic taxa, such as Buxus, Corylus and deciduous Quercus (Yll et al., 1997; Burjachs et al. 1994, 2017; Pérez-Obiol et al. 2000, 2001). This kind of vegetation takes advantage of wetter-than-today climate conditions and the absence of reported human activities until approximately the 5th-millennium cal BP. Both Mallorca and Menorca, known as the Gymnesic islands, show similar trends in vegetation history. From the 6th-to 4th-millennium cal BP, a deep vegetation shift occurred, implying a transition from the aforementioned mesic and littoral communities to Mediterranean macchia and garrigues dominated by Olea, Pistacia and Erica. These were prevalent plant communities during the Late Holocene, alternated with scattered open areas created for agropastoral activities. Such a deep landscape transformation has been related to the increasingly dry conditions in the Western Mediterranean and the possibility of agropastoral practices the archaeologically-documented definitive human occupation (Burjachs et al., 2017; Yll et al., 1999; Servera-Vives et al., 2018). Even though archaeological evidences before 2500-2800 cal BCE remain still controversial, pollen analysis carried out in Mallorca and Menorca evidence the increase of anthropogenic pollen indicators (including nitrophilous and ruderal taxa and crops), suggesting the possibility of agropastoral activities in the Balearic Islands prior to the Chalcolithic period (Carrión et al., 2010; Servera-Vives et al., 2018).

Despite the well-known high pollen productivity and overrepresentation of pine pollen grains in fossil and modern pollen analogue studies (Heim 1970; Ejarque et al., 2011; Miras 2009), Holocene paleoenvironmental littoral sequences from Mallorca and Menorca show low to moderate Pinus values, generally under $40 \%$. This fact has been interpreted as the scarce importance of pine formations on the Gymnesic islands during the Holocene, compared to Ibiza and other eastern Iberian Peninsula sequences. Despite the overall moderate pine representation in the Balearic Holocene sequences, it is worth noting an increase in Pinus values (from ca. $15 \%-40 \%$ ) reported in s'Albufera d'Alcúdia at ca. 3000-2000 cal BCE (Burjachs et al. 1994, 2017; Kaniewski et al., 2020), suggesting a change in the spread of littoral pine formations in the area. Other palynological studies from Holocene sequences in western Mallorca also show noticeable increases of Pinus values, such as in Santa Ponça (Parra 1994) and Palma Nova cores (Menéndez-Amor and Florschütz 1961), but no reliable chronological data are available.

\subsection{Mallorca during prehistory and protohistory}

The process of human occupation of the Balearic Islands occurred in a relatively late chronology in comparison with other insular territories of the Mediterranean basin. Archaeological evidence for the first human occupation of the archipelago remains slippery and under debate, but there is a consensus in situating the definitive settlement of human populations at around the first half of the 3rd-millennium cal. BCE (between 2900 and 2500 cal. BCE [Guerrero et al., 2007; Guerrero and Calvo 2008] and 2350-2150 cal. BCE [Alcover 2008; Lull et al., 2004; Sintes 2015]). The Chalcolithic occupation of Mallorca developed between c. 2500 and 1700 cal. BCE, representing stable human occupation of the island (Calvo and Guerrero, 2002; Calvo et al., 2002). Although the bioarchaeological information is scarce, it seems clear that from this period onwards, well-established agriculture and husbandry developed in the archipelago (Pérez-Jordà et al., 2018; Ramis 2018).

During the Bronze Age, the permanent occupation of all the biotopes of the island is well-evidenced, including the development of monumental vernacular architecture with cyclopean techniques. The socalled Naviform culture developed during the Bronze Age in 1700/ 1600-1100/1000-850 cal. BCE (Lull et al., 1999; Micó 2006; Guerrero et al., 2007; Calvo et al., 2011; Salvà 2013). During this period, settlements consisting of groups of navetiforms, monumental boat-shaped houses built using the cyclopean technique, expanded across the island of Mallorca and elsewhere in the archipelago.

After a period of transition and transformations in the Naviform culture, the Talaiotic culture (Early Iron Age [EIA], c.850-550 cal. BCE) emerged in Mallorca and Menorca. This culture is characterised by a redefinition of monumental architecture focused on public towershaped buildings (i.e., so-called 'talaiots' and other types of turriforms; Calvo 2009; Gelabert-Oliver et al., 2018). A new period of transformations occurred around c.550 cal. BCE, when the Postalaiotic or Balearic culture (Late Iron Age [LIA]) developed. The Postalaiotic or Balearic culture extended until the Roman conquest of the island in 123 cal. BCE.

\section{Materials and methods: archaeobotanical records of Pinus halepensis Miller}

Tracing the history of Aleppo pine woodlands on the island of Mallorca during the Late Holocene, including its anthropogenic use and potential influence on its distribution requires different kinds of archaeobotanical materials. Accordingly, this research is based on the compilation and analysis of published and unpublished charcoal and wooden fragments and pollen analysis of prehistoric and protohistoric archaeological sites on the island of Mallorca (Fig. 1) to gather information on both the landscape dynamics in the surroundings of the studied sites and on the management of woodlands by human communities. To summarise all the available datasets, we standardised and treated all the available data. The chronology of the available samples corresponds to the prehistory and protohistory of the island of Mallorca (c. 2300 cal. BCE-1st-century ADE). Samples from previous and later phases were scarce or did not meet the requirements for the data treatment proposed in this study (see below).

\subsection{Archaeological wood and charcoal remains}

Different wood and charcoal materials were considered in this study. Regarding charcoal assemblages, 37 samples of dispersed charcoal fragments from archaeological contexts with proper stratigraphic control and dating were analysed and considered (Table 1). As selection criteria for the samples to be analysed, we discarded those with less than $90 / 100$ charcoal fragments. All the selected samples had been previously evaluated in terms of statistical representativeness (see references in Table 1), and we took into consideration whether the samples came from demolished buildings after fire episodes.

To standardise the taxonomical identifications of all the samples by ecological types, different categories were established: xeric and subxeric trees, xeric and sub-xeric shrubs, and messic taxa. Pinus values were individualised in a separated category, and a sum of tree values was included. The taxonomical identifications included in each of these categories are shown in Table 2. With the 37 samples, anthracological diagrams were created for the three main biogeographical regions of the island: the Tramuntana mountain range in the north, the Pla (central plain), and the Llevant coast. A separate diagram was created for the site of Na Galera, located in a small islet on the western shores of Mallorca (Fig. 1).

Dendro-anthracological information regarding some of the Pinus halepensis fragments, which is also available (Picornell et al., 2020), was also considered. The objective of developing dendro-anthracological analysis of Aleppo pine charcoal fragments is to better define the pinewood exploitation practices developed by prehistoric communities in Mallorca by differentiating branches and/or trunk exploitation. The results of the dendro-anthracological analysis (charcoal-pith distance 


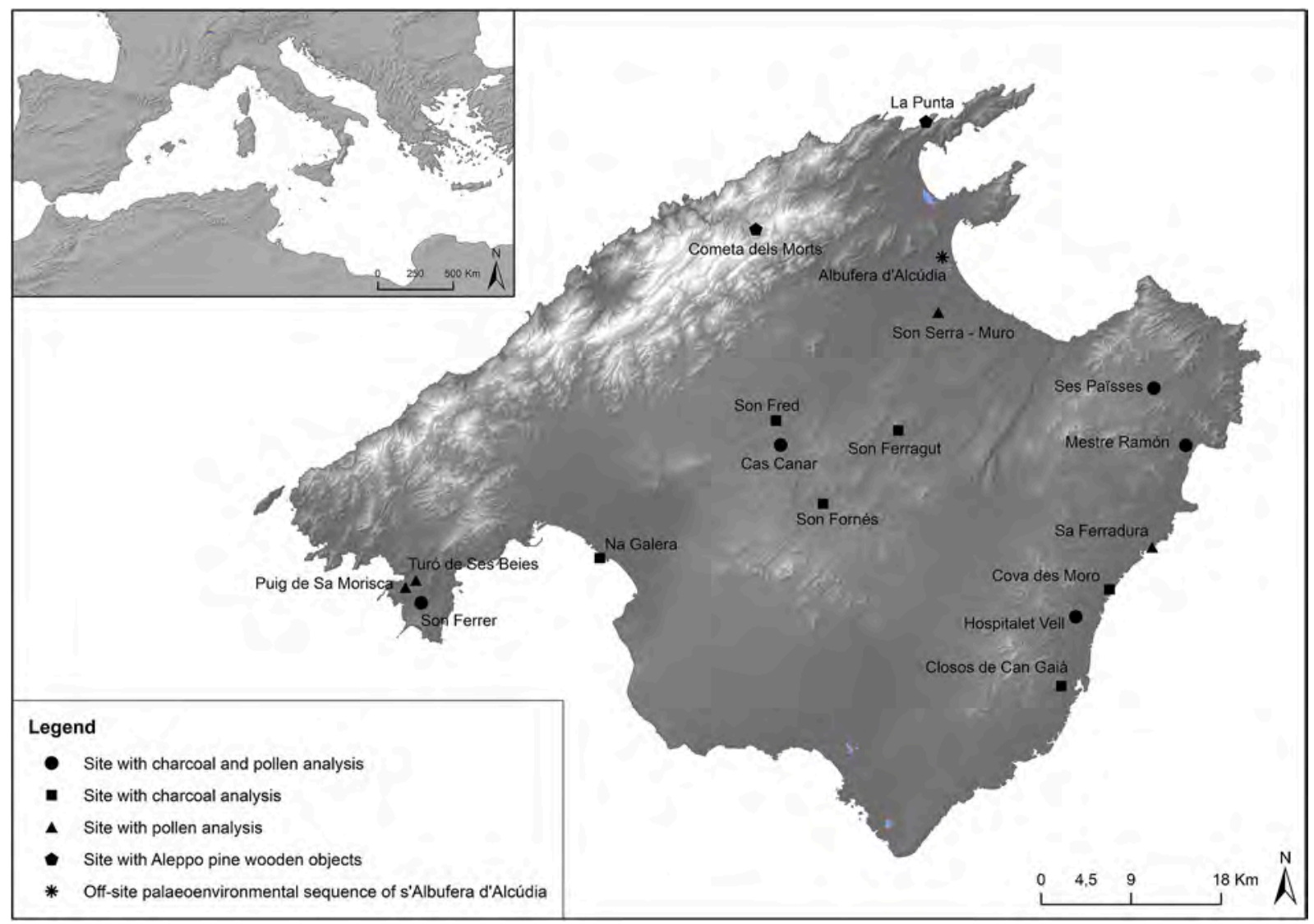

Fig. 1. Map of Mallorca island showing the location of the archaeological sites where charcoal and pollen assemblages were studied and of the off-site paleoenvironmental sequence of s'Albufera d'Alcúdia (drawn by Alejandra Galmés, Universitat de les Illes Balears).

combined with ring width) are organised according to anthraco-typological principles (Dufraisse et al., 2018; Coubrai and Dufraisse 2019). A dendrochronological referential study of Pinus halepensis Miller on Mallorca facilitated the establishment of four different anthraco-groups to differentiate different pinewood exploitation practices (Picornell et al., 2020):

Anthraco-group 1: A small diameter $(<7 \mathrm{~cm})$ and slow growth (RW $<1.5 \mathrm{~mm}$ ), represent branches;

Anthraco-group 2: A small diameter $(<7 \mathrm{~cm})$ and fast growth (RW $>$ $1.5 \mathrm{~mm}$ ) represent the internal part of mature woods from tunks Anthraco-group 3: A large diameter $(>7 \mathrm{~cm})$ and slow growth $(\mathrm{RW}<$ $1.5 \mathrm{~mm}$ ) represent external parts of major trunks characterised by slow growth

Anthraco-group 4: A large diameter $(>7 \mathrm{~cm})$ and fast growth $(\mathrm{RW}>$ $1.5 \mathrm{~mm}$ ) represent external parts of major trunks characterised by fast growth.

Dendro-anthracological analysis was performed on five of the available samples from three archaeological sites (Table 3). The results of the anthraco-typological analysis are represented in bar diagrams representing the percentage of fragments for each category in a given charcoal assemblage.

The study of archaeological objects or large fragments of wood identifiable as constructive elements also included Pinus halepensis macro-remains. The use of this wood to manufacture identifiable objects by prehistoric people has been documented in different funerary sites on the island, where the use of pinewood to make coffins to bury individuals has been documented (Picornell-Gelabert 2012; Calvo et al., 2020). Moreover, the use of pinewood to make different architectural elements has also been documented in prehistoric and protohistoric sites on the island. Both direct (i.e., burned wooden beams, posts and crosspieces) and indirect (i.e., diameter estimation of Pinus halepensis fragments in after-fire collapsed contexts where timber was burned and fragmented) evidence of timber use has been analysed in previous studies (Allué et al., 2013; Picornell-Gelabert 2012; Picornell Gelabert and Servera Vives, 2017; Piqué and Noguera 2003; Ros 1984; summarised in Dufraisse et al., 2018Dufraisse et al., 2018).

\subsection{Archaeopalinological materials and methods}

In this research, we gathered information from several archaeopalynological studies conducted on Mallorca. Forty-nine archaeopalynological samples from Mallorcan archaeological sites were selected for this study, ranging from the Llevant to the Tramuntana area (Table 4). To facilitate the comparison of archaeopalynological and anthracologial results, identifications were grouped following ecological Balearic categories, while Pinus pollen values were assigned to a separate category (Table 2). Samples were treated following different chemical procedures, including standard treatments (Faegri et al., 1989) and heavy liquid separation (see Table 4). For heavy liquid separation, two different methods were used in the palynological studies: (1) samples of about 2 gr. of dry sediment were treated for pollen extraction according to standard procedures using tetra-Na-pyrophosphate, $\mathrm{HCl}$ $10 \%$, acetolysis, heavy liquid separation with sodium metatungstate hydrate, HF 48\% and ethanol (Florenzano et al., 2012; van der Kaars et al., 2001), and (2) samples of about 15 gr. of dry sediment were treated using the standard procedures described by Girard and Renault Miskovsky (1969) and Goeury and de Beaulieu (1979), modified by Burjachs et al. (2003), including $\mathrm{HCl}, \mathrm{KOH}, \mathrm{HF}$ and heavy liquid $\mathrm{ZnCl2}$. In all cases, final residues were mounted on slides in glycerol jelly for pollen grains identification. Samples of a mean of 225 pollen grains 
Table 1

Description of the anthracological assemblages considered in this study.

\begin{tabular}{|c|c|c|c|c|c|c|c|c|}
\hline $\begin{array}{l}\text { Sample } \\
\text { code }\end{array}$ & Chronology & Site & Period & Biogeographical zone & Description & $\begin{array}{l}\text { Fire } \\
\text { episode }\end{array}$ & $\begin{array}{l}n \\
\text { frags }\end{array}$ & Reference \\
\hline CG1 & $1770-1520 \mathrm{cal} \mathrm{BC}$ & Closos & Naviform & Llevant & $\begin{array}{l}\text { Domestic space previous to } \\
\text { the construction of the } \\
\text { Navetiform } 1\end{array}$ & - & 426 & $\begin{array}{l}\text { Picornell-Gelabert and } \\
\text { Servera Vives (2017) }\end{array}$ \\
\hline CG2 & $1300-920$ cal BC & Closos & Naviform & Llevant & $\begin{array}{l}\text { Domestic use of the } \\
\text { Navetiform 1, Phase } 1\end{array}$ & - & 265 & $\begin{array}{l}\text { Picornell Gelabert and } \\
\text { Servera Vives (2017) }\end{array}$ \\
\hline CG3 & $1020-830 \mathrm{cal} \mathrm{BC}$ & Closos & Naviform & Llevant & $\begin{array}{l}\text { Domestic use of the } \\
\text { Navetiform 1, Phase } 2\end{array}$ & - & 621 & $\begin{array}{l}\text { Picornell-Gelabert and } \\
\text { Servera Vives (2017) }\end{array}$ \\
\hline CG4 & $1040-820 \mathrm{cal} \mathrm{BC}$ & Closos & Naviform & Llevant & $\begin{array}{l}\text { Last level of the Navetiform } \\
1 \text {, roof collapse }\end{array}$ & - & 634 & $\begin{array}{l}\text { Picornell Gelabert and } \\
\text { Servera Vives (2017) }\end{array}$ \\
\hline HV_N3_1 & $1500-1400 \mathrm{cal} \mathrm{BC}$ & Hospitalet & Naviform & Llevant & $\begin{array}{l}\text { Last level of the Navetiform } \\
3 \text {, roof collapse }\end{array}$ & + & 458 & $\begin{array}{l}\text { Picornell-Gelabert and } \\
\text { Servera Vives (2017) }\end{array}$ \\
\hline HV_N3_2 & $1000-900 \mathrm{cal} \mathrm{BC}$ & Hospitalet & Naviform & Llevant & $\begin{array}{l}\text { Domestic use of the } \\
\text { Navetiform } 3\end{array}$ & - & 642 & $\begin{array}{l}\text { Picornell Gelabert and } \\
\text { Servera Vives (2017) }\end{array}$ \\
\hline HV_N4_1 & $1621-1502$ cal BC & Hospitalet & Naviform & Llevant & $\begin{array}{l}\text { Domestic use of the } \\
\text { Navetiform 4, Phase } 1\end{array}$ & - & 99 & $\begin{array}{l}\text { Picornell Gelabert and } \\
\text { Servera Vives (2017) }\end{array}$ \\
\hline HV_N4_2 & $1606-1427 \mathrm{cal} \mathrm{BP}$ & Hospitalet & Naviform & Llevant & $\begin{array}{l}\text { Domestic use of the } \\
\text { Navetiform 4, Phase } 2\end{array}$ & - & 157 & $\begin{array}{l}\text { Picornell-Gelabert and } \\
\text { Servera Vives (2017) }\end{array}$ \\
\hline SP1 & $700-450 \mathrm{cal} \mathrm{BC}$ & Ses Païsses & Talayotic & Llevant & $\begin{array}{l}\text { Domestic use Building 25, } \\
\text { Phase I }\end{array}$ & - & 145 & $\begin{array}{l}\text { Picornell Gelabert and } \\
\text { Servera Vives (2017) }\end{array}$ \\
\hline SP2 & $350-200 \mathrm{cal} \mathrm{BC}$ & Ses Païsses & Postalayotic & Llevant & $\begin{array}{l}\text { Domestic use Building 25, } \\
\text { Phase II }\end{array}$ & - & 1202 & $\begin{array}{l}\text { Picornell Gelabert and } \\
\text { Servera Vives (2017) }\end{array}$ \\
\hline SP3 & $200-125 \mathrm{cal} \mathrm{BC}$ & Ses Païsses & Postalayotic & Llevant & $\begin{array}{l}\text { Domestic use Building 25, } \\
\text { Phase III }\end{array}$ & - & 438 & $\begin{array}{l}\text { Picornell Gelabert and } \\
\text { Servera Vives (2017) }\end{array}$ \\
\hline SP4 & $\begin{array}{l}123 \text { BC - S. I cal } \\
\text { AC }\end{array}$ & Ses Païsses & $\begin{array}{l}\text { Postalayotic - } \\
\text { Transition } \\
\text { Roman }\end{array}$ & Llevant & $\begin{array}{l}\text { Domestic use Building 25, } \\
\text { Phase IV }\end{array}$ & - & 125 & $\begin{array}{l}\text { Picornell Gelabert and } \\
\text { Servera Vives (2017) }\end{array}$ \\
\hline SP5 & $1212-1005$ cal BC & Ses Païsses & Late Bronze Age & Llevant & Domestic use, Building 51-1 & + & 409 & $\begin{array}{l}\text { Picornell Gelabert and } \\
\text { Servera Vives (2017) }\end{array}$ \\
\hline SP6 & $1000-850 \mathrm{cal} \mathrm{BC}$ & Ses Païsses & Late Bronze Age & Llevant & Domestic use, Building 51-2 & + & 243 & $\begin{array}{l}\text { Picornell Gelabert and } \\
\text { Servera Vives (2017) }\end{array}$ \\
\hline SP7 & $1000-850 \mathrm{cal} \mathrm{BC}$ & Ses Païsses & Late Bronze Age & Llevant & Fallen roof, Building 51-2 & + & 568 & $\begin{array}{l}\text { Picornell Gelabert and } \\
\text { Servera Vives (2017) }\end{array}$ \\
\hline SP8 & $800-450 \mathrm{cal} \mathrm{BC}$ & Ses Pïsses & $\begin{array}{l}\text { Talayotic/ } \\
\text { Postalayotic }\end{array}$ & Llevant & $\begin{array}{l}\text { Occupation layer, Building } \\
51-4\end{array}$ & - & 226 & $\begin{array}{l}\text { Picornell Gelabert and } \\
\text { Servera Vives (2017) }\end{array}$ \\
\hline SP9 & c. $600 \mathrm{cal} \mathrm{BC}$ & Ses Pïsses & Talayotic & Llevant & $\begin{array}{l}\text { Occupation layer, Building } \\
\text { 13, Phase I }\end{array}$ & + & 404 & $\begin{array}{l}\text { Picornell Gelabert and } \\
\text { Servera Vives (2017) }\end{array}$ \\
\hline SP10 & c. $400 \mathrm{cal} \mathrm{BC}$ & Ses Pïsses & Postalayotic & Llevant & $\begin{array}{l}\text { Occupation layer, Building } \\
\text { 13, Phase III }\end{array}$ & - & 310 & $\begin{array}{l}\text { Picornell Gelabert and } \\
\text { Servera Vives (2017) }\end{array}$ \\
\hline SP11 & $200-100$ cal BC & Ses Païsses & Postalayotic & Llevant & $\begin{array}{l}\text { Occupation layer, Building } \\
\text { 13, Phase IV }\end{array}$ & - & 263 & $\begin{array}{l}\text { Picornell Gelabert and } \\
\text { Servera Vives (2017) }\end{array}$ \\
\hline SP12 & $200-100 \mathrm{cal} \mathrm{BC}$ & Ses Païsses & Postalayotic & Llevant & $\begin{array}{l}\text { Occupation layer, Building } \\
\text { 14, Phase I }\end{array}$ & + & 344 & $\begin{array}{l}\text { Picornell Gelabert and } \\
\text { Servera Vives (2017) }\end{array}$ \\
\hline SP13 & $200-100 \mathrm{cal} \mathrm{BC}$ & Ses Païsses & Postalayotic & Llevant & $\begin{array}{l}\text { Occupation layer, Building } \\
\text { 14, Phase II }\end{array}$ & + & 314 & $\begin{array}{l}\text { Picornell Gelabert and } \\
\text { Servera Vives (2017) }\end{array}$ \\
\hline SP14 & $300-200$ cal BC & Ses Païsses & Postalayotic & Llevant & $\begin{array}{l}\text { Occupation layer, Building } \\
\text { 14, Phase I }\end{array}$ & - & 134 & $\begin{array}{l}\text { Picornell Gelabert and } \\
\text { Servera Vives (2017) }\end{array}$ \\
\hline SP15 & c. $450 \mathrm{cal} \mathrm{BC}$ & Ses Païsses & Postalayotic & Llevant & $\begin{array}{l}\text { Occupation layer Buiding } 13 \\
\text { Phase II }\end{array}$ & - & 88 & $\begin{array}{l}\text { Picornell Gelabert and } \\
\text { Servera Vives (2017) }\end{array}$ \\
\hline SF1 & $899-810$ cal BC & Son Fornés & Talayotic & Central plain & $\begin{array}{l}\text { Occupation level, follen } \\
\text { roof, Talayot } 3\end{array}$ & + & 511 & $\begin{array}{l}\text { Picornell-Gelabert } \\
\text { (2012) }\end{array}$ \\
\hline SF2 & S. IV cal BC & Son Fornés & Postalayotic & Central plain & $\begin{array}{l}\text { Occupation level, follen } \\
\text { roof, Talayot } 3\end{array}$ & + & 703 & $\begin{array}{l}\text { Picornell-Gelabert } \\
\text { (2012) }\end{array}$ \\
\hline SF3 & S. IV cal BC & Son Fornés & Postalayotic & Central plain & Occupation level, Talayot 3 & + & 398 & $\begin{array}{l}\text { Picornell-Gelabert } \\
\text { (2012) }\end{array}$ \\
\hline SF4 & S. II-I cal BC & Son Fornés & $\begin{array}{l}\text { Postalayotic - } \\
\text { Transition } \\
\text { Roman }\end{array}$ & Central plain & $\begin{array}{l}\text { Occupation level, } \\
\text { refurbishing of Talayot } 3\end{array}$ & - & 209 & $\begin{array}{l}\text { Picornell-Gelabert } \\
\text { (2012) }\end{array}$ \\
\hline TSF1 & $450-200 \mathrm{cal} \mathrm{BC}$ & Son Ferrer & Postalayotic & $\begin{array}{l}\text { Tramuntana mountain } \\
\text { range }\end{array}$ & $\begin{array}{l}\text { Funerary use of fire in } \\
\text { collective necropolis }\end{array}$ & - & 405 & $\begin{array}{l}\text { Picornell-Gelabert and } \\
\text { Dufraisse (2018) }\end{array}$ \\
\hline CC1 & $901-841 \mathrm{cal} \mathrm{BC}$ & Ca's Canar & Talayotic & Central plain & $\begin{array}{l}\text { Occupation level, follen } \\
\text { roof, square Talayot }\end{array}$ & + & 489 & Allué and Euba, 2013 \\
\hline SFD1 & $830-530 \mathrm{cal} \mathrm{BC}$ & Son Fred & Talayotic & Central plain & $\begin{array}{l}\text { Occupation level, follen } \\
\text { roof, Talayot }\end{array}$ & + & 293 & Carrión 2009 \\
\hline SFT1 & $750-475 \mathrm{cal} \mathrm{BC}$ & $\begin{array}{l}\text { Son } \\
\text { Ferragut }\end{array}$ & Talayotic & Central plain & $\begin{array}{l}\text { Domestic use, fallen roof, } \\
\text { house Edificio Alfa }\end{array}$ & + & 2715 & Piqué y Noguera (2003) \\
\hline SF5 & $850-550$ cal BC & Son Fornés & Talayotic & Central plain & $\begin{array}{l}\text { Domestic use, different } \\
\text { houses of the settlement }\end{array}$ & $+/-$ & 1166 & Piqué y Noguera (2002) \\
\hline SF6 & $400-200 \mathrm{cal} \mathrm{BC}$ & Son Fornés & Postalayotic & Central plain & $\begin{array}{l}\text { Domestic use, different } \\
\text { houses of the settlement }\end{array}$ & $+/-$ & 331 & Piqué y Noguera (2002) \\
\hline SF7 & S. II-I cal BC & Son Fornés & $\begin{array}{l}\text { Postalayotic - } \\
\text { Transition } \\
\text { Roman }\end{array}$ & Central plain & $\begin{array}{l}\text { Domestic use, different } \\
\text { houses of the settlement }\end{array}$ & $+/-$ & 647 & Piqué y Noguera (2002) \\
\hline MR1 & S. II BC & & & Llevant & & - & 334 & \\
\hline
\end{tabular}


Table 1 (continued)

\begin{tabular}{|c|c|c|c|c|c|c|c|c|}
\hline $\begin{array}{l}\text { Sample } \\
\text { code }\end{array}$ & Chronology & Site & Period & Biogeographical zone & Description & $\begin{array}{l}\text { Fire } \\
\text { episode }\end{array}$ & $\begin{array}{l}n \\
\text { frags }\end{array}$ & Reference \\
\hline & & $\begin{array}{l}\text { Mestre } \\
\text { Ramón }\end{array}$ & $\begin{array}{l}\text { Postalayotic - } \\
\text { Transition } \\
\text { Roman }\end{array}$ & & $\begin{array}{l}\text { Use as dump of the corridor } \\
\text { of a Talayotic staggered } \\
\text { cyclopean structure }\end{array}$ & & & $\begin{array}{l}\text { Hernández-Gasch et al. } \\
\text { (2020) }\end{array}$ \\
\hline CM1 & $\begin{array}{l}\text { End of the IIIth } \\
\text { Millennium cal } \\
\text { BC }\end{array}$ & $\begin{array}{l}\text { Cova des } \\
\text { Moro }\end{array}$ & Calcolithic & Llevant & $\begin{array}{l}\text { Funerary use of a natural } \\
\text { cave }\end{array}$ & - & 466 & Carrión in preparation \\
\hline NG1 & 1st Century AD & Na Galera & Early Roman & $\begin{array}{l}\text { Small islet close to the } \\
\text { coast in the Palma Bay }\end{array}$ & $\begin{array}{l}\text { Secondary deposition of } \\
\text { charcoal fragments in a } \\
\text { cistern reused as a dump pit }\end{array}$ & - & 329 & Carrión Marco, 2019 \\
\hline
\end{tabular}

Table 2

Taxa grouping according to phytosociological formations and climatic conditions in the Balearic Islands (according to Bolós 1993; Gil et al., 2003; Llorens et al., 2007).

\begin{tabular}{|c|c|c|}
\hline $\begin{array}{l}\text { Taxa grouping } \\
\text { according to } \\
\text { climatic } \\
\text { conditions }\end{array}$ & Pollen taxa grouping & Anthracology taxa grouping \\
\hline Pinus sp. & Pinus sp. & $\begin{array}{l}\text { Pinus t. halepensis } \\
\text { Pinus t. pinea }\end{array}$ \\
\hline $\begin{array}{l}\text { Xeric \& Sub-xeric } \\
\text { trees }\end{array}$ & $\begin{array}{l}\text { Quercus ilex/coccifera, Olea, } \\
\text { Juniperus }\end{array}$ & $\begin{array}{l}\text { Quercus ilex/coccifera, Olea, } \\
\text { Juniperus }\end{array}$ \\
\hline$\Sigma$ trees & $\begin{array}{l}\text { SUM Trees, excluding } \\
\text { cultivated }\end{array}$ & $\begin{array}{l}\text { SUM Trees, excluding } \\
\text { cultivated }\end{array}$ \\
\hline $\begin{array}{l}\text { Xeric \& Sub-xeric } \\
\text { shrubs }\end{array}$ & $\begin{array}{l}\text { Pistacia, Erica, Arbutus, Cistus, } \\
\text { Rosmarinus, Helianthemum, } \\
\text { Lavandula, Hypericum, } \\
\text { Rhamnus, Phillyrea, Genista, } \\
\text { Ephedra }\end{array}$ & $\begin{array}{l}\text { Pistacia, Erica, Arbutus, } \\
\text { Cistus, Rosmarinus, } \\
\text { Lavandula, Lamiaceae, } \\
\text { Rhamnus, Phillyrea, } \\
\text { Fabaceae, Clematis, Ephedra, } \\
\text { Thymelaea/Daphne }\end{array}$ \\
\hline Messic taxa & $\begin{array}{l}\text { Buxus, Castanea, Alnus, } \\
\text { Corylus, deciduous Quercus, } \\
\text { Abies, Betula, Fagus, Ulmus, } \\
\text { Tilia, Carpinus, Fraxinus, } \\
\text { Myrtus }\end{array}$ & $\begin{array}{l}\text { Buxus, Alnus, deciduous } \\
\text { Quercus, Ulmus, Fraxinus, } \\
\text { Laurus nobilis, Pistacia t. } \\
\text { terebinthus, Myrtus sp., Acer, } \\
\text { Taxus, Prunus, Hedera, } \\
\text { Maloideae }\end{array}$ \\
\hline Poaceae & Poaceae & Non existing \\
\hline Herbs & Herbs excluding Poaceae & Non existing \\
\hline
\end{tabular}

counted per slide were considered. Pollen relative values were calculated as percentages of the total land pollen sum, which includes pollen from vascular plants. Pollen grains were identified and counted using biological microscopes at magnifications typically ranging from 400 to 630. Pollen identification was carried out using atlases and morphological keys (e.g., Punt et al. 1976-2009; Moore et al., 1991; Reille, 1992; Beug, 2004). Diagrams were plotted using C2 software (Juggins 2007) and refined in Illustrator.

\section{Results}

\subsection{Archaeological wood and charcoal analysis}

Thirty-seven assemblages of dispersed charcoal fragments were considered in this study (Table 1): 25 from the Llevant coast, 10 from the central plain, 1 from the Tramuntana mountain range and 1 from the islet of Na Galera (Fig. 2).

The Llevant region has the best chronological coverage, with samples from the Early Bronze Age to the 1st century ACE originating from five different archaeological sites. The different taxonomical categories change over time, and the values of Pinus are variable, ranging from $0 \%$ to $40 \%$. In the central plain, 10 samples from 4 different sites were analysed, all of which correspond to the EIA and LIA. The values are homogenous during the first part of the diagram, but changes are detected in the last part of the sequence, when Pinus values increase significantly.

The only assemblage available in the Tramuntana mountain range corresponds to the LIA use of the Son Ferrer hypogeum as a collective burial place. In this assemblage, Pinus presents significant values, but the most represented taxonomical category corresponds to xeric and subxeric shrubs. Finally, in Na Galera islet, an assemblage of charcoal fragments deposited in a dump pith over a relatively long period of time during the 1st century ACE was studied. In this case, Pinus is the most recurrent taxon identified.

The results of the dendro-anthracological analysis of Pinus halepensis charcoal fragments (Picornell-Gelabert et al., 2020) allowed us to organise the results obtained (Table 5) according to anthraco-typological principles, represented in Fig. 3, which shows the percentage of analysed fragments for each of the four anthraco-groups. The two Late Bronze Age levels analysed at Building 51 of Ses Païsses showed predominance of anthraco-group 1 (representing branches), especially in the habitat layer. In contrast, the LIA assemblages from Building 25 at Ses Païsses and Talaiot 3 at Son Fornés were characterised by the clear predominance of anthraco-group 2 and the highest values for anthraco-group 4 detected among the five assemblages. These results indicate that the Pinus fragments originated from both trunks and branches. Finally, the assemblage from Na Galera also showed a predominance of anthraco-group 1, followed by anthraco-group 2. Some of these results invite reconsideration of the nature and origin of the dispersed charcoal fragments and reevaluation of the context, as timber remains may have also been present (Picornell-Gelabert et al., 2020).

Regarding direct evidences of timber wood, a total of 133 architectural wooden elements were identified in Bronze and Iron Age sites on Mallorca (Table 6). In all cases, the timber elements were preserved after a fire event that caused the collapse of a building. The only direct evidence of timber in Bronze Age sites corresponds to two Olea beam fragments from a Navetiform at the Hospitalet Vell site. In Iron Age sites, a larger amount of architectural timber remains is present at the sites of Cas Canar, Son Ferragut and Son Fornés. Most of the timber elements correspond to Olea europaea, but a significant amount of Pinus halepensis elements were also found at all of the sites, especially at Cas Canar.

Finally, Pinus wood was also used as a raw material to manufacture objects (Table 7). In all cases, Pinus wooden objects were found in LIA funerary sites and are related to the wooden coffins (Picornell-Gelabert 2012; Calvo et al., 2002a).

\subsection{Archaeopalynology}

Forty-nine samples were considered in this study: 35 in Llevant, 3 in Pla, and 11 in Tramuntana regions (Fig. 4). Overall, the studied archaeopalynological samples showed relatively low values of Pinus pollen (i.e., under $22 \%$ ). This is consistent with the general moderate-tolow AP values (generally under 40\%). The chronology of the samples differed from one region to another. The Llevant region presented samples from four sites with a wide time span, from the Bronze Age to Roman times. These samples contained the highest values of Pinus pollen of all the samples presented in this study, with maximal values of ca. $22 \%$. During the Bronze Age, samples from S'Hospitalet Vell and Sa Ferradura recorded the highest values of pine pollen. Later, during the First Iron Age, moderate values (ca. 10-20\%) of xeric and sub-xeric trees 


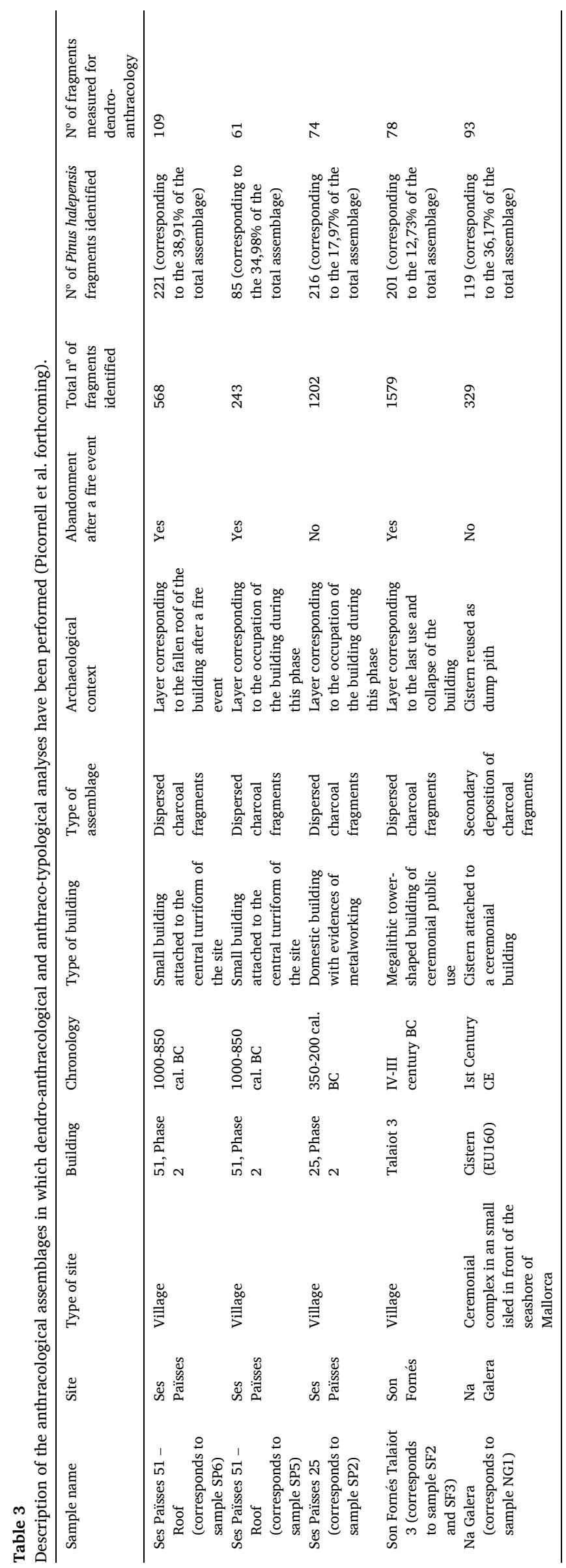

are recorded, and very low values of messic (e.g., Buxus, Corylus and Alnus). During LIA and Roman times, an overall trend toward lower Pinus values is highlighted in the diagram, coinciding with a noticeable increase in herbaceous taxa.

The three archaeopalynological samples from the Pla region show almost no pine pollen, with maximal values of about $1 \%$, while AP values were always below $6 \%$. Samples from Son Serra-Muro were quite similar, even if they corresponded to different chronologies, while Cas Canar samples showed relatively higher values of arboreal and shrubby taxa. Regarding the Tramuntana region, the highest values of Pinus pollen were recorded at the site of Turó de Ses Beies (ca. 13\%). Additionally, during the LIA, most samples showed higher values of xeric and sub-xeric trees, messic taxa, and AP but lower values of xeric and subxeric shrubs. TSF-56, from Tumul de Son Ferrer, was the only sample with Roman chronology in the Tramuntana region and showed a predominance of herbaceous taxa.

\section{Discussion}

\subsection{Pinewood exploitation on Mallorca during prehistory and protohistory}

The use of pinewood by prehistoric groups on Mallorca is well attested from the end of the Chalcolithic, when the first anthracological assemblages appear (CM1, Fig. 2). The presence of pine charcoal fragments is ubiquitous in all regions and phases, but the percentages change from one period to the other. Regarding the archaeopalynological record, percentages of pine pollen grains vary from region to region and period to period. However, high percentages of pine pollen are not detected in any of the assemblages, with values always under $20 \%$, and there are samples in all regions that barely register this species (Fig. 4), even if pines are great pollinators (Räsänen et al., 2007; Fall 2012; Heim, 1970). Although pollen is not readily preserved in archaeopalynological samples, such studies have proven their value in reconstructing human activities and landscape dynamics (Florenzano et al., 2013; Mercuri et al., 2019). Moreover, Pinus is considered a species with high preservation ability (Cao et al., 2007).

The archaeopalynological analyses show a mainly open landscape in the surroundings of the studied sites, ranging from open to semi-open environments, with an overall predominance of herbaceous taxa in all regions and chronologies. Poaceae pollen is well-detected in all samples, reaching important percentages in many cases and confirming the existence of open areas near the sites. Accordingly, archaeopalynological results suggest that the landscape surrounding the prehistoric settlements on Mallorca were open landscapes in which crop fields and pasturelands were farmed since the settlement of the Naviform villages (Mercuri et al., 2019), as also attested by carpological results (Pérez-Jordà and Peña-Chocarro, 2018). The territories adjacent to human settlements would then be characterised by a mosaic landscape composed of a patchy distribution of crop fields, pasturelands and woody vegetal formations characterised by macchia-like scrublands. This anthropogenic landscape structure appears to have been maintained over the last four millennia, as it has also been suggested in off-site pollen sequences from both Mallorca and Menorca (Burjachs et al., 2017; Servera-Vives et al., 2018). Accordingly, heterogeneous distributions and densities of pine forests could have occurred across the island, which could explain the differences observed in the charcoal record. The use of very local resources could also have increased these differences (Fig. 2).

The area of Llevant presents the most ancient assemblages of both charcoal and pollen, as well as the longest sequence in time, from the end of the 3rd Millennium cal. BCE to the 1st century ACE (Figs. 2 and 4). There are moderate percentages of pine pollen in the oldest sample from a navetiform domestic unit at Hospitalet Vell and in EIA samples, but they decrease significantly during the LIA. Moderate pine pollen values were also recorded in LBA samples from the rocky headland of Sa 
Table 4

Description of the archaeopalynological assemblages considered in this study.

\begin{tabular}{|c|c|c|c|c|c|c|}
\hline Sample code & Chronology & Site & Period & $\begin{array}{l}\text { Biogeographical } \\
\text { zone }\end{array}$ & $\begin{array}{l}\text { Chemical } \\
\text { procedure }\end{array}$ & Reference \\
\hline Casc/Talaiot S & ca. $650 \mathrm{BC}$ & Cas Canar & Talaiotic & Pla & Standard & Llergo and Riera Mora (2010) \\
\hline MR-M-29 & $\begin{array}{l}\text { 2nd half } 6 \text { th } \mathrm{c} \text {. } \\
\mathrm{BC}\end{array}$ & Mestre Ramon & Postalaiotic & Llevant & Standard & $\begin{array}{l}\text { Servera-Vives and Currás (2017a); Hernández-Gasch et al., } \\
\text { (2020) }\end{array}$ \\
\hline MR-C-110 & Early Iron Age & Mestre Ramon & Talaiotic & Llevant & Heavy liquid & $\begin{array}{l}\text { Servera-Vives and Currás (2017a); Hernández-Gasch et al., } \\
\text { (2020) }\end{array}$ \\
\hline MR-C-77 & Iron Age & Mestre Ramon & $\begin{array}{l}\text { Talaiotic/ } \\
\text { postalaiotic }\end{array}$ & Llevant & Heavy liquid & $\begin{array}{l}\text { Servera-Vives and Currás (2017a); Hernández-Gasch et al., } \\
\text { (2020) }\end{array}$ \\
\hline MR-C-121 & Late Bronze Age & Mestre Ramon & Late Bronze Age & Llevant & Heavy liquid & $\begin{array}{l}\text { Servera-Vives and Currás (2017a); Hernández-Gasch et al., } \\
\text { (2020) }\end{array}$ \\
\hline MR-C-88 & 2nd c. BC & Mestre Ramon & Postalaiotic & Llevant & Heavy liquid & $\begin{array}{l}\text { Servera-Vives and Currás (2017a); Hernández-Gasch et al., } \\
\text { (2020) }\end{array}$ \\
\hline MR-C-45 & 2nd c. BC & Mestre Ramon & Postalaiotic & Llevant & Standard & $\begin{array}{l}\text { Servera-Vives and Currás (2017a); Hernández-Gasch et al., } \\
\text { (2020) }\end{array}$ \\
\hline MR-C-33 & 2nd c. BC & Mestre Ramon & Postalaiotic & Llevant & Standard & $\begin{array}{l}\text { Servera-Vives and Currás (2017a); Hernández-Gasch et al., } \\
\text { (2020) }\end{array}$ \\
\hline PSM-1 & 4th c. BC & Puig Sa Morisca & Postalaiotic & Tramuntana & Standard & Llergo and Riera (2010) \\
\hline PSM-2 & 4th c. BC & Puig Sa Morisca & Postalaiotic & Tramuntana & Standard & Llergo and Riera (2010) \\
\hline PSM-6 & 4th c. BC & Puig Sa Morisca & Postalaiotic & Tramuntana & Standard & Llergo and Riera (2010) \\
\hline PSM-7 & 850-700 вС & Puig Sa Morisca & Talaiotic & Tramuntana & Standard & Llergo and Riera (2010) \\
\hline PSM-8 & $850-700 \mathrm{BC}$ & Puig Sa Morisca & Talaiotic & Tramuntana & Standard & Llergo and Riera (2010) \\
\hline SFE-18 & $\begin{array}{l}1200 / 1100-900 \\
\text { BC }\end{array}$ & Sa Ferradura & Late Bronze Age & Llevant & Standard & $\begin{array}{l}\text { Servera-Vives and Currás (2017b); Picornell-Gelabert and } \\
\text { Servera-Vives (2019) }\end{array}$ \\
\hline SFE-59 & $\begin{array}{l}1200 / 1100-900 \\
\text { BC }\end{array}$ & Sa Ferradura & Late Bronze Age & Llevant & Standard & $\begin{array}{l}\text { Servera-Vives and Currás (2016b); Picornell-Gelabert and } \\
\text { Servera-Vives (2019) }\end{array}$ \\
\hline SFE-73 & $\begin{array}{l}1200 / 1100-900 \\
\text { BC }\end{array}$ & Sa Ferradura & Late Bronze Age & Llevant & Standard & $\begin{array}{l}\text { Servera-Vives and Currás (2016b); Picornell-Gelabert and } \\
\text { Servera-Vives (2019) }\end{array}$ \\
\hline SFE-83 & $\begin{array}{l}1200 / 1100-900 \\
\text { BC }\end{array}$ & Sa Ferradura & Late Bronze Age & Llevant & Standard & $\begin{array}{l}\text { Servera-Vives and Currás (2016b); Picornell-Gelabert and } \\
\text { Servera-Vives (2019) }\end{array}$ \\
\hline SFE-85 & $\begin{array}{l}1200 / 1100-900 \\
\text { BC }\end{array}$ & Sa Ferradura & Late Bronze Age & Llevant & Standard & $\begin{array}{l}\text { Servera-Vives and Currás (2016b); Picornell-Gelabert and } \\
\text { Servera-Vives (2019) }\end{array}$ \\
\hline SP-76N & $758-416$ BC & Ses Païsses & Talaiotic & Llevant & Standard & Llergo and Riera Mora (2010) \\
\hline SP-80 & $770-480 \mathrm{BC}$ & Ses Païsses & Talaiotic & Llevant & Standard & Llergo and Riera Mora (2010) \\
\hline SP-50-100 Pit & ca. $600 \mathrm{BC}$ & Ses Païsses & Talaiotic & Llevant & Standard & Llergo and Riera Mora (2010) \\
\hline SP-27 & ca. $1100 \mathrm{BC}$ & Ses Païsses & Late Bronze Age & Llevant & Standard & Llergo and Riera Mora (2010) \\
\hline SP-26 & ca. $1100 \mathrm{BC}$ & Ses Païsses & Late Bronze Age & Llevant & Standard & Llergo and Riera Mora (2010) \\
\hline SP-25 & ca. $1100 \mathrm{BC}$ & Ses Païsses & Late Bronze Age & Llevant & Standard & Llergo and Riera Mora (2010) \\
\hline SP-21 & ca. $1100 \mathrm{BC}$ & Ses Païsses & Late Bronze Age & Llevant & Standard & Llergo and Riera Mora (2010) \\
\hline SP-20B & ca. $1100 \mathrm{BC}$ & Ses Païsses & Late Bronze Age & Llevant & Standard & Llergo and Riera Mora (2010) \\
\hline $\begin{array}{l}\text { SP-35-ditch } \\
\quad \text { filling }\end{array}$ & 1st c. BC & Ses Païsses & Roman Times & Llevant & Standard & Burjachs (2005) \\
\hline $\begin{array}{l}\text { SP-72/wall } \\
\text { building }\end{array}$ & 4th c. BC & Ses Païsses & Postalaiotic & Llevant & Standard & Burjachs (2005) \\
\hline $\begin{array}{l}\text { SHV-H-G9D/ } \\
\text { UE57 }\end{array}$ & Late Iron Age & $\begin{array}{l}\text { S'Hospitalet Vell- } \\
\text { rooms }\end{array}$ & Postalaiotic & Llevant & Heavy liquid & Servera-Vives \& Currás (2016a) \\
\hline $\begin{array}{l}\text { SHV-H-Q8D } \\
\text { UE57 }\end{array}$ & Late Iron Age & $\begin{array}{l}\text { S'Hospitalet Vell- } \\
\text { rooms }\end{array}$ & Postalaiotic & Llevant & Heavy liquid & Servera-Vives \& Currás (2016a) \\
\hline $\begin{array}{l}\text { SHV-H-Q9D } \\
\text { UE58 }\end{array}$ & Late Iron Age & $\begin{array}{l}\text { S'Hospitalet Vell- } \\
\text { rooms }\end{array}$ & Postalaiotic & Llevant & Heavy liquid & Servera-Vives \& Currás (2016a) \\
\hline SHV-H-34 & Late Iron Age & $\begin{array}{l}\text { S'Hospitalet Vell- } \\
\text { rooms }\end{array}$ & Postalaiotic & Llevant & Heavy liquid & Servera-Vives \& Currás (2016a) \\
\hline SHV-H-5H & Late Iron Age & $\begin{array}{l}\text { S'Hospitalet Vell- } \\
\text { rooms }\end{array}$ & Postalaiotic & Llevant & Heavy liquid & Servera-Vives \& Currás (2016a) \\
\hline SHV-H-41 & Late Iron Age & $\begin{array}{l}\text { S'Hospitalet Vell- } \\
\text { rooms }\end{array}$ & Postalaiotic & Llevant & Heavy liquid & Servera-Vives \& Currás (2016a) \\
\hline SHV-P-34 & Late Iron Age & $\begin{array}{l}\text { S'Hospitalet Vell- } \\
\text { rooms }\end{array}$ & Postalaiotic & Llevant & Heavy liquid & Servera-Vives \& Currás (2016a) \\
\hline SHV-H-58 & Late Iron Age & $\begin{array}{l}\text { S'Hospitalet Vell- } \\
\text { rooms }\end{array}$ & Postalaiotic & Llevant & Heavy liquid & Servera-Vives \& Currás (2016a) \\
\hline SHV-P-41 & Late Iron Age & $\begin{array}{l}\text { S'Hospitalet Vell- } \\
\text { rooms }\end{array}$ & Postalaiotic & Llevant & Heavy liquid & Servera-Vives \& Currás (2016a) \\
\hline SHV-H-40 & Late Iron Age & $\begin{array}{l}\text { S'Hospitalet Vell- } \\
\text { rooms }\end{array}$ & Postalaiotic & Llevant & Heavy liquid & Servera-Vives \& Currás (2016a) \\
\hline SHV-N-23 & Bronze Age & $\begin{array}{l}\text { S'Hospitalet Vell- } \\
\text { Naveta }\end{array}$ & Naviform & Llevant & Heavy liquid & Yll et al. (2010) \\
\hline SHV-T-72 & Early Iron Age & $\begin{array}{l}\text { S'Hospitalet Vell- } \\
\text { Talaiot }\end{array}$ & Talaiotic & Llevant & Heavy liquid & Yll et al. (2010) \\
\hline SHV-T-77 & Early Iron Age & $\begin{array}{l}\text { S'Hospitalet Vell- } \\
\text { Talaiot }\end{array}$ & Talaiotic & Llevant & Heavy liquid & Yll et al. (2010) \\
\hline SSE-8 & $1020-830$ BC & Son Serra-Muro & Late Bronze Age & Pla & Heavy liquid & Servera-Vives and Currás (2016b) \\
\hline SSE-18 & Roman Times & Son Serra-Muro & Roman Times & Pla & Heavy liquid & Servera-Vives and Currás (2016b) \\
\hline TSF-65 & $900-700$ BC & Túmul de Son Ferrer & Talaiotic & Tramuntana & Heavy liquid & Picornell-Gelabert and Dufraisse (2018) \\
\hline TSF-17 & $\begin{array}{l}1130-900 / 850 \\
\text { BC }\end{array}$ & Túmul de Son Ferrer & Late Bronze Age & Tramuntana & Heavy liquid & Picornell-Gelabert and Dufraisse (2018) \\
\hline
\end{tabular}


Table 4 (continued)

\begin{tabular}{|c|c|c|c|c|c|c|}
\hline Sample code & Chronology & Site & Period & $\begin{array}{l}\text { Biogeographical } \\
\text { zone }\end{array}$ & $\begin{array}{l}\text { Chemical } \\
\text { procedure }\end{array}$ & Reference \\
\hline TSF-56 & $100 \mathrm{BC}-100 \mathrm{AD}$ & Túmul de Son Ferrer & Roman Times & Tramuntana & Heavy liquid & Picornell-Gelabert and Dufraisse (2018) \\
\hline $\begin{array}{l}\text { TSB-13 (XXVIII/ } \\
\text { 5) }\end{array}$ & $200-75$ BC & Turó Ses Beies & Postalaiotic & Tramuntana & Standard & Llergo et al. (2010) \\
\hline $\begin{array}{l}\text { TSB-13 (XXVIII/ } \\
10)\end{array}$ & $200-75$ BC & Turó Ses Beies & Postalaiotic & Tramuntana & Standard & Llergo et al. (2010) \\
\hline TSB-17 (XXX,G) & $200-75$ BC & Turó Ses Beies & Postalaiotic & Tramuntana & Standard & Llergo et al. (2010) \\
\hline
\end{tabular}

Ferradura. The use of pine wood shown in the anthracological record was variable during Bronze Age in this region, as some assemblages do not contain pine fragments (e.g., sample HV_N3_1) or contain minor percentages, and some have higher representations of pine. The highest values were recorded at Building 51 of the Ses Païsses site. In this case, dendro-anthracological research has shown that even if the building was abandoned after a fire episode (Table 1 ), what could cause the burning and subsequent fragmentation of pine timber and/or material culture, thus resulting in an overrepresentation of this taxon in the studied charcoal assemblage, the assemblages are mainly composed of pine branches (Fig. 3). This is especially clear in the habitat layer (SP6), and only in the fallen roof layer (SP7) are a few fragments of trunks detected. Accordingly, it has been suggested that like the rest of the Bronze Age assemblages of the Llevant area, samples from Building 51 represent the use of pine branches as firewood, although a possible use of some timber elements made out of pinewood cannot be discarded (Picornell-Gelabert et al., 2020). Archaeopalynological samples from Building 51 of Ses Paiisses show a decrease in woodland formations from the preparation levels $(20 \mathrm{~B}, 21)$ to the occupation ones $(25,26,27)$, while pine pollen value remain low and do not show significative variation suggesting that pine formation or not well stablished in the area and/or that pine wood exploitation do not imply significant decrease in their extension.

Later on, during the EIA and LIA, pine charcoal percentages increase significantly, reaching values of $>30 \%$, in the two studied sites presenting assemblages from this periods, Ses Païsses and Mestre Ramon (Fig. 2). The increase is significantly relevant in LIA assemblages. In this sense, the dendro-anthracological analysis shows that in Building 25 of Ses Païsses, pine branches and trunks were both used as firewood during the LIA (Fig. 3), meaning that firewood procurement involved cutting down pine trees (Picornell-Gelabert et al., 2020). This is relevant considering that at Building 25, evidence of metallurgical activity was found (Aramburu 2009; Picornell Gelabert and Servera Vives, 2017), suggesting that increasing firewood demand may have resulted in cutting down pine trees to meet the fuel requirements of metallurgical production. This fact, together with the significant increase of pine values in the LIA anthraological assemblages in the Llevant, suggests that pinewood was a more relevant energetic resource during this period than in previous BA contexts. This is consistent with archaeopalynological data, which highlights the low representativity of pine communities in the Llevant area during the LIA.

A similar trend is shown in the central plain, where EIA and LIA charcoal assemblages at four different archaeological sites were analysed (Fig. 2). During the EIA, the highest pine values were detected at the Cas Canar site. In this case, the studied assemblage collected from the interior of a square talaiot (i.e., a tower-shaped public monument) rather than from a domestic space (Table 1). This monumental building was abandoned after a fire event, after which 101 wooden beams were preserved, 22 of them corresponding to pine (Table 6). In this sense, it has been argued that pine would be overrepresented in the anthracological assemblage after the burning and fragmentation of timber (Picornell-Gelabert 2012; Allué and Euba, 2013). In any case, the 22 pine beams clearly show that in this region, pine trees were cut down during EIA and their trunks used as timber. This is especially relevant considering the absence of pine pollen from the EIA sample from this same site and the very minor values in the other sites of this region
(Fig. 4), suggesting that pine would not have been a recurrent species in the surroundings. Accordingly, it can be suggested that pines were especially targeted for use as timber, which would have required relatively long trips to reach pine populations, cut their trunks and transport them to the site.

In the same region, pine timber was also identified during the LIA. Direct evidence is found at Son Ferragut (two beams and one crosspiece) and Cas Canar (a wooden beam) (Table 6). Moreover, the dendroanthracological analysis at Talaiot 3 of Son Fornés also showed the exploitation of pine trunks (Fig. 3). Considering that the LIA charcoal assemblage from this tower-shaped monument was formed after a fire event (Table 1), it has been suggested that the recurrence of fragments originating from pine trunks would be the result of the burning and fragmentation of pine timber elements, probably beams from the roof of the talaiot (Picornell-Gelabert et al., 2020). However, most of the wooden constructive elements found in these sites are made of Olea trunks (Table 6). This can also be explained by the fact that as archaeopalynological records indicate, pine would not be a recurrent species in the area. However, during the LIA, there was a relevant increase in the use of pine firewood in domestic spaces of Son Fornés (Fig. 2), suggesting that this species was especially appreciated as firewood during the LIA, as already proposed for the Llevant region. This increase in the use of pine firewood in the central plain during the LIA would also involve the organisation of trips from the villages to pine woodlands which, according to the archaeopalynological results, would be distant from the settlements.

The other two regions present a smaller number of studied assemblages. In the case of the Serra de Tramuntana, only one charcoal assemblage was studied, corresponding to the LIA funerary use of the hypogeum of the Son Ferrer staggered turriform (Fig. 2, Table 1). In this case, high pine percentages were recorded, corresponding to the use of firewood during successive inhumations in the cave (Picornell-Gelabert and Dufraisse, 2018). This suggests that pinewood was also appreciated as firewood in ritual and funerary contexts during the LIA. Son Ferrer is located near the coast at the western end of the Tramuntana mountain range, in the same regions of the three sites presenting archaeopalynological analyses (Fig. 1). In this area, pine pollen is better represented in the LBA sample, while it is rare in EIA and Roman samples (Fig. 4). Nevertheless, during the LIA, pine higher pollen values were recorded in samples from the Turó de ses Beies, suggesting that pine populations were better represented in the neighbouring area of the Santa Ponça coastal lagoon.

In the case of the islet of $\mathrm{Na}$ Galera, the charcoal assemblage from a cistern reused as a dump pit during the 1st century ACE shows the highest pine percentages recorded among the studied samples. This assemblage corresponds to the successive deposition of charcoal debris into the dump over a relatively long period of time. The dendroanthracological study of this assemblage (Fig. 3) shows that it was mainly composed of pine branches, which indicates that the assemblage represents the deposition of firewood debris. However, some fragments corresponding to trunks are detected, which could also represent firewood debris or the cleaning of pine timber elements from a neighbouring building that burned down at the time (Picornell-Gelabert et al., 2020). Accordingly, the assemblage suggests that pine provided most of the firewood used during the 1st century ACE. Since it is a secondary 


\section{LLEVANT}
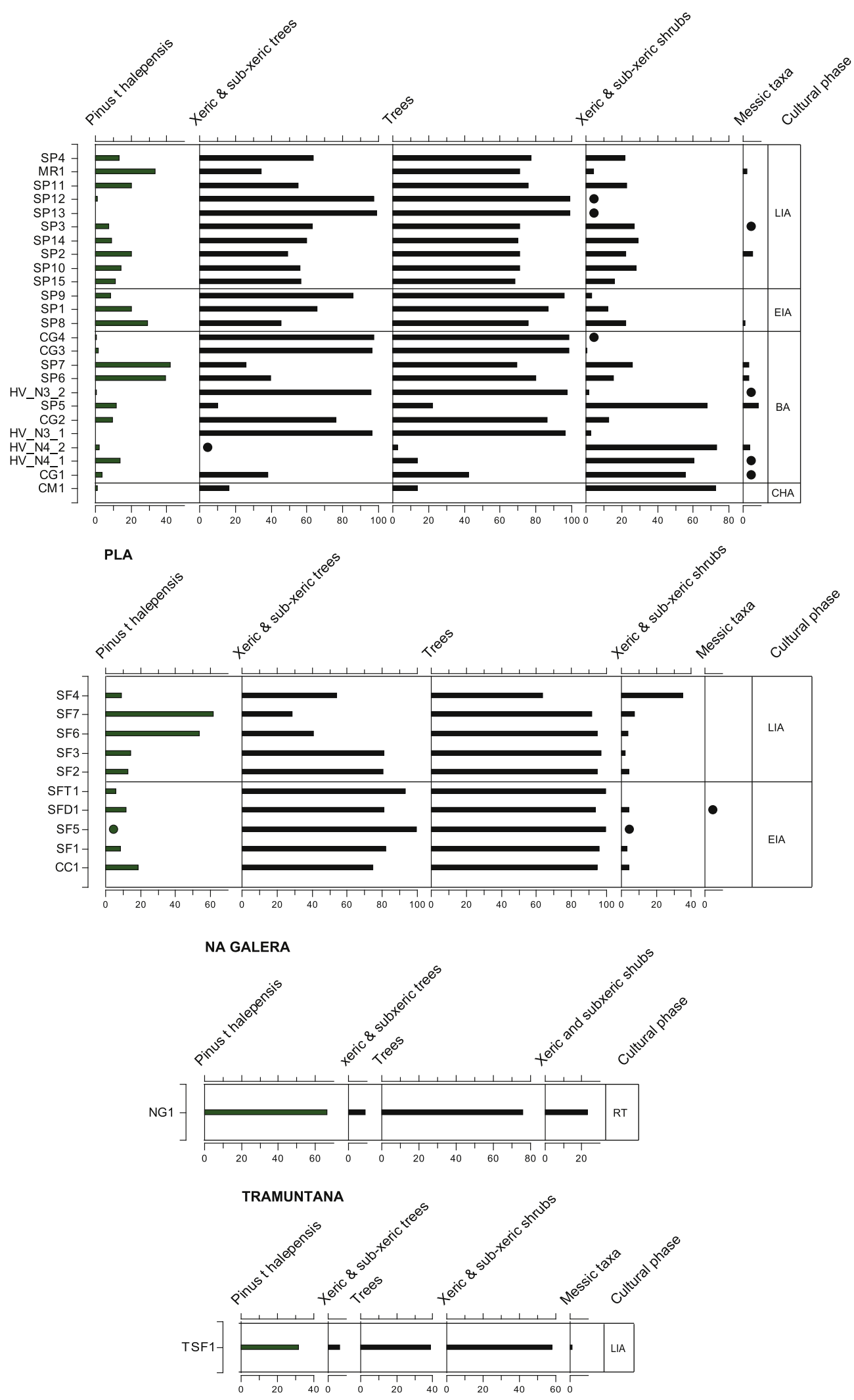

Fig. 2. Percentage diagrams of anthracological data for the different regions of Mallorca: eastern coast (Llevant), central plain (Pla), Tramuntana mountain range (Tramuntana) and Na Galera islet. The results are plotted following their chronology. Horizontal lines indicate chrono-cultural phases: BA (Bronze Age); EIA (Early Iron Age); LIA (Late Iron Age); RT (Roman Times). 
Table 5

Results of the anthraco-typological analysis (Picornell-Gelabert et al. forthcoming).

\begin{tabular}{|c|c|c|c|c|c|c|c|c|c|c|}
\hline \multirow[t]{3}{*}{ Anthraco-group } & \multirow{2}{*}{\multicolumn{2}{|c|}{$\frac{\text { Galera }}{\text { SU160 }}$}} & \multicolumn{6}{|c|}{ Ses Païsses } & \multirow{2}{*}{\multicolumn{2}{|c|}{$\frac{\text { Son Fornés }}{\text { Talaiot } 3}$}} \\
\hline & & & \multicolumn{2}{|c|}{ 51-Roof } & \multicolumn{2}{|c|}{ 51-Habitat } & \multicolumn{2}{|c|}{ Ed. 25} & & \\
\hline & $\mathrm{n}$ & $\%$ & $\mathrm{n}$ & $\%$ & $\mathrm{n}$ & $\%$ & $\mathrm{n}$ & $\%$ & $\mathrm{n}$ & $\%$ \\
\hline 1 & 58 & 62,37 & 53 & 48,62 & 44 & 72,13 & 16 & 21,62 & 10 & 12,82 \\
\hline 2 & 30 & 32,26 & 47 & 43,12 & 15 & 24,59 & 46 & 62,16 & 44 & 56,41 \\
\hline 3 & 1 & 1,08 & 4 & 3,67 & 2 & 3,28 & 2 & 2,70 & 6 & 7,69 \\
\hline 4 & 4 & 4,30 & 5 & 4,59 & & 0 & 10 & 13,51 & 18 & 23,08 \\
\hline Total frags. & 93 & 100 & 109 & 100 & 61 & 100 & 74 & 100 & 78 & 100 \\
\hline
\end{tabular}
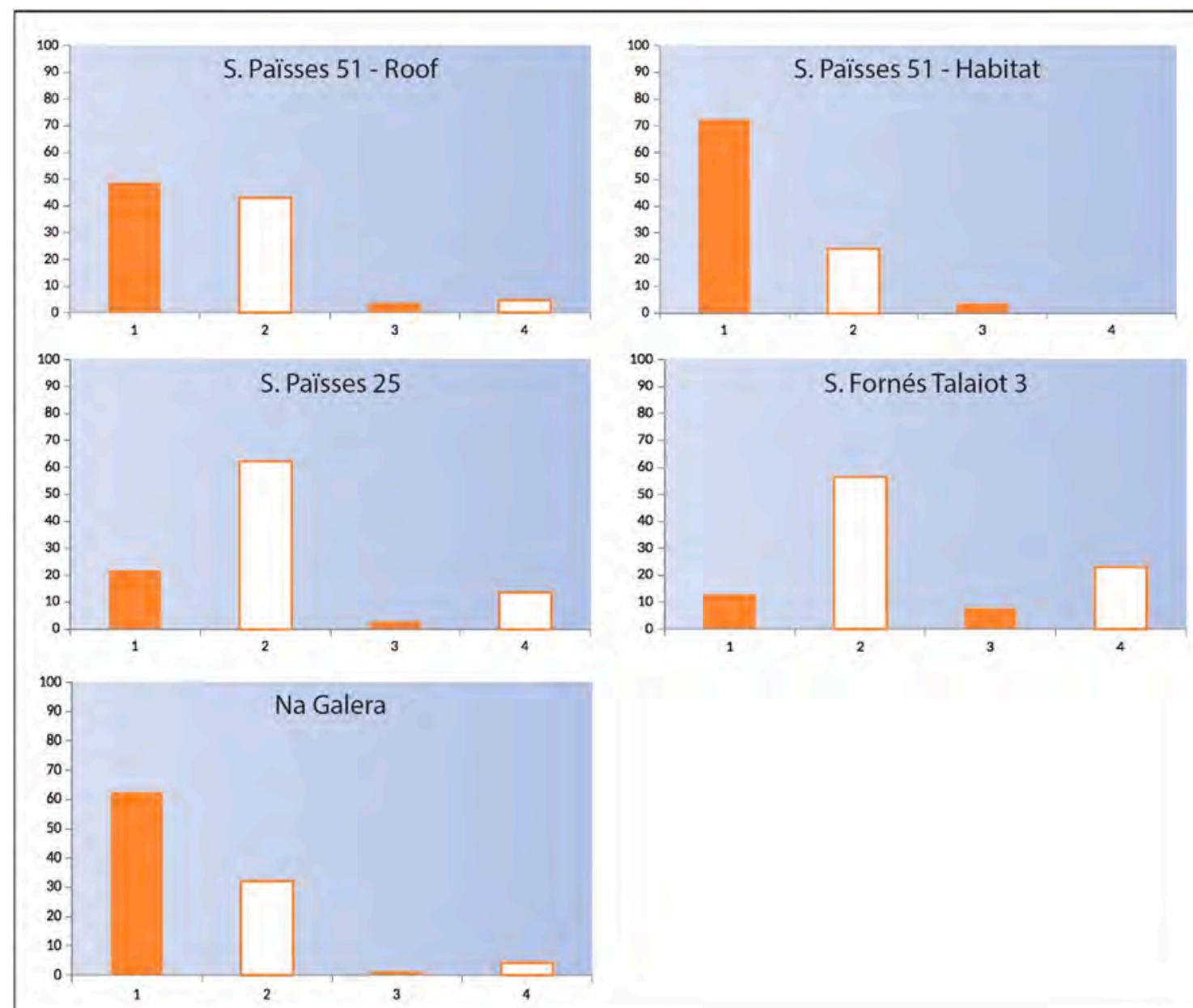

Fig. 3. Bar charts showing the percentage of fragments for the four different anthraco-groups in each assemblage.

deposition of firewood debris, it is difficult to assess the original use of fire. In the small islet where the archaeological site is located, both ceremonial and metallurgical activities were documented. Moreover, the small size and the lack of soils in the islet suggest that firewood would have been transported from Mallorca, probably after the exploitation of coastal vegetation. Hence, as it is documented at Son Ferrer and other LIA sites from the other regions, pine branches appear to be a relevant fuel resource.

Altogether, the charcoal and pollen results both show that Aleppo pine had been present in the vegetal landscape of Mallorca island since the beginning of the permanent occupation of all the biotopes by sedentary human groups practising long-lasting agricultural and pastoral activities. Pinewood was exploited in all regions and periods to fulfil different social demands, such as firewood and timber. However, both the distribution of pine woodlands and their exploitation appear to have changed over time. During the Bronze Age, the exploitation of pinewood as fuel is well attested in the Llevant region, but its use is irregular among the studied sites and, when present, presents minor values. In any case, it is relevant the presence of domestic contexts with no charcoal fragments from this species. Moreover, the use of pinewood as timber is not well documented, as only a few charcoal fragments resulting from trunks (anthraco-group 4) were included in the dendro-anthracological analysis of the fallen roof layer of Building 51 at Ses Païsses.

This situation changes during later phases. During the EIA, pine percentages increase in the anthracological record in the two regions where assemblages were studied, the Llevant and the central plain. At this time, clear exploitation of pine trunks as constructive timber is welldocumented at the Cas Canar site. Subsequently, pine percentages increase significantly in LIA anthracological assemblages in all the studied regions, showing a clear preference for using this species as firewood in both domestic and ritual contexts. In Building 25 of Ses Païsses, this clear increase in the use of pine firewood is also related to the cutting 
Table 6

Summary of the direct evidences of timber remains identified in prehistoric and protohistoric sites in Mallorca (after Picornell and Dufraisse et al., 2018).

\begin{tabular}{|c|c|c|c|c|c|}
\hline Site & Period & Type of building & $\begin{array}{l}\text { Type of constructive } \\
\text { element }\end{array}$ & $\begin{array}{l}\mathrm{N}^{\circ} \text { of constructive elements } \\
\text { identified }\end{array}$ & $\begin{array}{l}\text { Taxonomical } \\
\text { identification }\end{array}$ \\
\hline $\begin{array}{l}\text { Hospitalet } \\
\text { Vell }\end{array}$ & Bronze Age - Navetic & Navetiform house (domestic space) & Beams form the roof & 2 & Olea europaea \\
\hline \multirow[t]{2}{*}{ Son Fornés } & $\begin{array}{l}\text { Early Iron Age - } \\
\text { Talayotic }\end{array}$ & Various houses (domestic spaces) & Beams form the roof & Indet. $^{a}$ & Olea europaea \\
\hline & $\begin{array}{l}\text { Late Iron Age - } \\
\text { Postalayotic }\end{array}$ & Talaiot 3 (public space) & $\begin{array}{l}\text { Beam form the roof/upper } \\
\text { floor }\end{array}$ & 1 & Olea europaea \\
\hline \multirow[t]{2}{*}{ Son Ferragut } & $\begin{array}{l}\text { Late Iron Age - } \\
\text { Postalayotic }\end{array}$ & Building Alfa, house (domestic space) & Beams form the roof & $\begin{array}{l}9 \\
2\end{array}$ & $\begin{array}{l}\text { Olea europaea } \\
\text { Pinus halepensis }\end{array}$ \\
\hline & & & Cross pieces & $\begin{array}{l}14 \\
1\end{array}$ & $\begin{array}{l}\text { Olea europaea } \\
\text { Pinus halepensis }\end{array}$ \\
\hline \multirow[t]{2}{*}{ Cas Canar } & $\begin{array}{l}\text { Early Iron Age - } \\
\text { Talayotic }\end{array}$ & Square Talaiot (public building) & $\begin{array}{l}\text { Beams form the roof/upper } \\
\text { floor }\end{array}$ & $\begin{array}{l}75 \\
22 \\
3 \\
1\end{array}$ & $\begin{array}{l}\text { Olea europaea } \\
\text { Pinus halepensis } \\
\text { Rhamnus/Phillyrea sp. } \\
\text { Pistacia lentiscus }\end{array}$ \\
\hline & $\begin{array}{l}\text { Late Iron Age - } \\
\text { Postalayotic }\end{array}$ & $\begin{array}{l}\text { Building "Recinto 3", attached to the } \\
\text { square talaiot }\end{array}$ & Beams from the roof & $\begin{array}{l}1 \\
1\end{array}$ & $\begin{array}{l}\text { Pistacia lentiscus } \\
\text { Pinus halepensis }\end{array}$ \\
\hline
\end{tabular}

${ }^{\text {a }}$ The timber remains identified in Talaiotic houses of Son Fornés site by Ros (1984) have been counted as 1, as the author does not provide a quantification of the identified remains but states that all of them corresponds to Olea europaea.

Table 7

Summary of the Pinus halepensis wooden objects identified in prehistoric sites of Mallorca (after Picornell-Gelabert 2012).

\begin{tabular}{llll}
\hline Type of object & Site & Chronology & Reference \\
\hline $\begin{array}{l}\text { Different articulated } \\
\text { elements of the zoomorph }\end{array}$ & La Punta & Late Iron & $\begin{array}{l}\text { Picornell-Gelabert } \\
\text { Age }\end{array}$ \\
$\begin{array}{lll}\text { wooden coffins } \\
4 \text { monoxilous wooden }\end{array}$ & $\begin{array}{l}\text { Cometa } \\
\text { coffins }\end{array}$ & Late Iron & \\
1 mortise of the mortise- & Cometa & Age & \\
and-tenon joints of the & dels Morts & Age & \\
wooden coffins & & & \\
1 cover of wooden coffin & Cometa & Late Iron & \\
& dels Morts & Age & \\
\hline
\end{tabular}

down of pine trees to fulfil the energetic demand of metallurgical activities, a case that is also possible at the Na Galera site. Moreover, the use of pine trunks as constructive timber is also well-documented with both direct (burnt beams) and indirect (dendro-anthracological analyses in burnt contexts) evidence (Picornell-Gelabert et al., 2018b; Picornell-Gelabert et al., 2020). In this same period, the use of pinewood as raw material is documented for wooden object manufacturing (Table 7). Pinewood was frequently used to manufacture different elements of wooden coffins, including the coffin itself, as well as covers and mortise-and-tenon joinery elements (Picornell-Gelabert 2012). The size of these elements, especially coffins and covers, shows that only trunks would be large enough to create the cavities that hosted the body of the deceased. Hence, again, the cutting of pines to use their trunks is also attested in these LIA contexts.

When comparing anthracological and archaeopalynological results, it seems clear that it was during the LIA when human groups targeted the exploitation of pines. This is especially relevant in the case of the central plain, where a clear increase in the use of pine firewood and pine trunks as constructive timber occurs in a region where pine pollen percentages are significantly low (or even absent), suggesting a cultural choice that involved transportation of pine wood from distant areas to the sites. Aleppo pine trees produce a relevant amount of deadwood, representing $>70 \%$ of the deadwood in current Balearic forests (IFN 2012). Even if Aleppo pine is not a self-pruning tree (Ne'eman et al., 2004), the production of deadwood in the lower parts of the trunk would have created a reservoir of easily reachable dry wood to be used as firewood. As it has been pointed out, this fuel resource was exploited during all the studied periods, but it is particularly appreciated during LIA in domestic, metallurgical and ritual contexts. In this period, the practise of cutting down pine trees for use as fuel for metallurgical activities, timber procurement and objects manufacturing is well documented.

\subsection{Late Holocene Aleppo pine woodlands in Mallorca}

Aleppo pine has been considered by many authors to be a species linked to the stages of early succession and degradation of other forest formations, such as Quercus and other broadleaved trees (Bellot 1978; Peinado Lorca, 1987). In many palaeobotanical sequences, an expansion of this species is documented from the introduction of farming, without ruling out that it was also favoured by its adaptability to temperature and aridity increase (Martínez del Castillo et al., 2018). The ecological role of Mediterranean pines has been largely discussed, including whether its expansion is a consequence of major human landscape disturbances or it is driven by its particular adaptation to certain climatic and edaphic tough conditions (e.g., Barbéro et al., 1998; Quézel and Barbero 1992; Ne'eman and Trabaud 2000). Serotony and early flowering of Aleppo pine are considered favourable traits to survive crown fires (Tapias et al., 2004; Daskalakou and Thanos 1996; Thanos and Daskalakou 2000; Ne'eman et al., 2004; Ne'eman and Izhaki 2006; Pausas et al., 2004). Accordingly, it is considered to be a pioneer and an invasive tree in Mediterranean environments (Pausas et al., 2002). However, even if the adaptive and reproductive strategies of this tree have generally been explained after its adaptation to post-fire regeneration and colonisation, recent research agrees in highlighting other relevant constraints to which pines are especially adapted, such as drought and unstable edaphic conditions, which would also explain its regeneration and expansion (Ne'eman et al., 2004).

Archaeobotanical and paleoenvironmental literature on the Western Mediterranean has often discussed this subject. In Mediterranean Iberia, Aleppo pine is one of the most extended trees in thermo- and mesoMediterranean formations (Rivas Martínez, 1987). As in the Balearics, phytosociology has discussed the 'naturalness' of Aleppo pine populations in Iberia and their current distribution, which remains a matter of debate (Aranbarri et al., 2020). The adaptation of this tree to especially unstable edaphic conditions, as well as its post-fire regenerative capacity and subsequent pioneering role, have been considered the explanation for the development of Aleppo pine woodlands after human disturbances (Costa 1987; Braun-Blanquet and Bolós, 1987Braun-Blanquet and Bolós, 1987; Quézel and Barbero, 1990Quézel and Barbero, 1990). However, paleoenvironmental research has often found this specific explanation, based on current vegetation observations, to be problematic in explaining the trends and dynamics of Holocene vegetation (Carrión et al., 2010; Carrión and Fernández, 2009).

The Holocene dynamics of Aleppo pine woodlands in the Ebro basin were recently reviewed by Aranbarri et al. (2020), who concluded that 

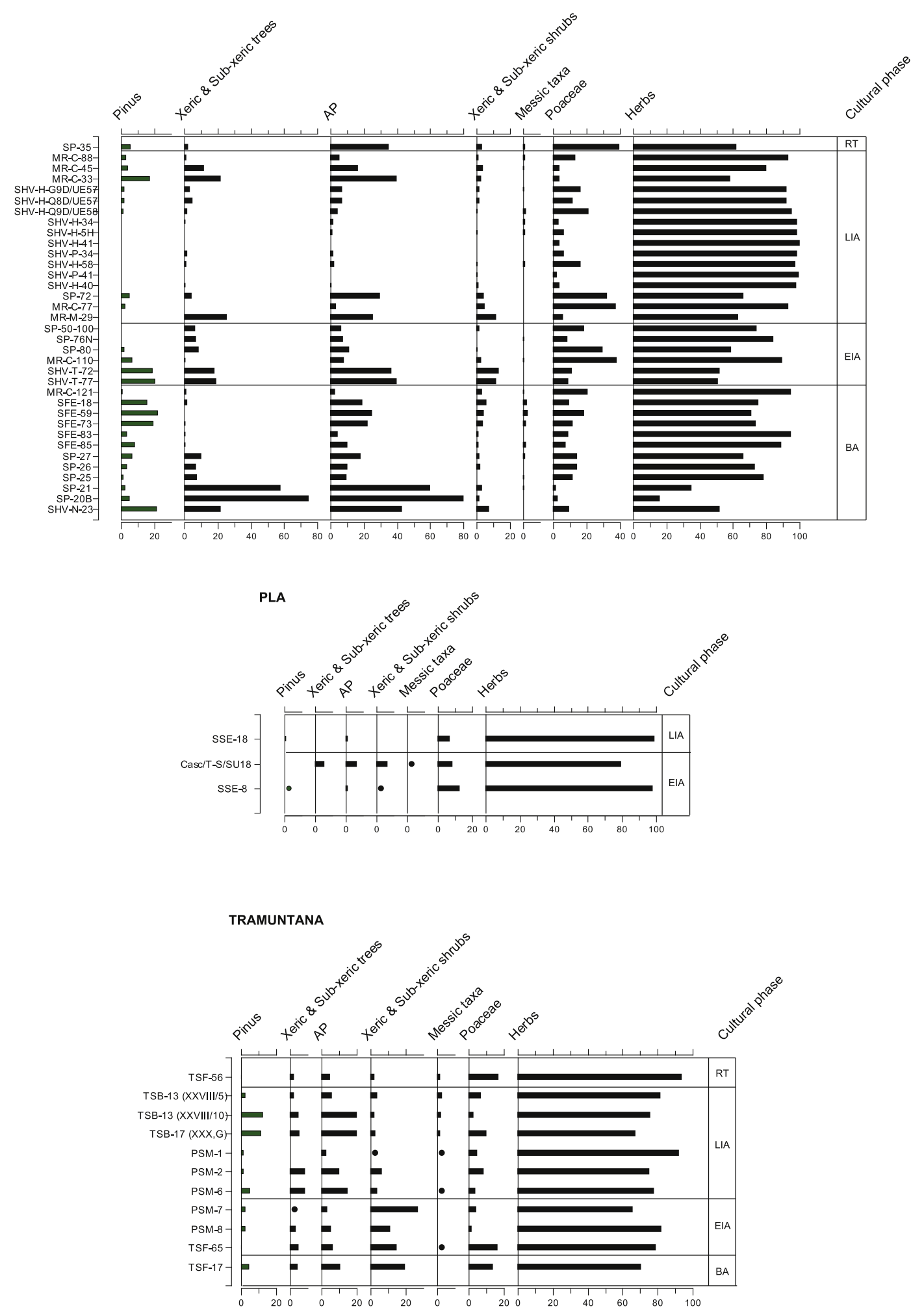

Fig. 4. Percentage diagram of archaeopalynological data for the different regions of Mallorca: eastern coast (Llevant), central plain (Pla) and Tramuntana mountain range (Tramuntana). The results are plotted following their chronology. Horizontal lines indicate chrono-cultural phases: BA (Bronze Age); EIA (Early Iron Age); LIA (Late Iron Age); RT (Roman Times).

the current distribution of this species is explained by anthropogenic environmental degradation and as a consequence of other factors, such as long-term responses to climate changes and edaphic conditions. The expansion of Aleppo pine woodlands appears to have been well-documented since the Mesolithic period (Aranbarri et al., 2020;
Badal 2013). Accordingly, its distribution before the onset of human landscape transformations during the Neolithic period is considered the result of natural vegetation dynamics and the adaptation of this species to the climatic and edaphic conditions of the region. In fact, they consider that Neolithic Aleppo pine's decreased presence in 
anthracological and palynological records is the result of the development of more messic environmental conditions. They also refer to climatic instability detected during the Bronze and Iron Ages, which favoured the spread of macchia and pine formations at the expense of broadleaved forests (Aranbarri et al., 2020).

In northeastern Iberia, the Holocene development of Aleppo pine woodlands is well-documented along the coast, especially south of the Llobregat river and has been attributed to a north-south gradient of increasing aridity and seasonality (Allue et al., 2017; Burjachs et al., 2000; Carrión Marco, 2003; Grau Almero and Duque, 2007). Such climatic trends would explain the spread of not only pine formations but also macchia-like scrublands in the region during the Mid and Late Holocene periods. Accordingly, these vegetation dynamics on the Mediterranean coast of Iberia have been interpreted as a differentiated trend in relation to central European dynamics, according to which aridity and seasonality rather than a human disturbance of broadleaved formations would explain the prehistoric development of both pine woodlands and macchia (Allue et al., 2017; Carrión et al., 2010; Carrión et al. 2011). In the context of discussing the prehistoric anthropogenic impacts causing vegetation changes in the northeastern Mediterranean region, the well-documented prehistoric anthracological records of the Garraf area do not reflect a decrease in broadleaved forests and a subsequent development of Aleppo pine woodlands after anthropogenic landscape impacts. Neither Neolithic nor Bronze or Iron Age human activities in the landscape, which would include bushfires and timber and firewood procurement, seem to have induced a significant decrease in broadleaved forests (Quercus) and a parallel spread of pine species. The increase/decrease of Aleppo pine in the anthracological record is parallel to the representation of xeric and thermophilic shrubs. This is why its development is considered a climate-related dynamic, due to aridity and seasonality increases, rather than human-induced processes after major landscape degradation (Allue et al., 2017).

Further south, Aleppo pine is also a key element in the Holocene woodlands of eastern and southeastern Iberia. Paleobotanical data have allowed documenting the presence of the Aleppo pine during the Last Glacial Maximum and the Late Glacial period in some areas of southern and eastern Iberia (Badal 1998; Aura et al., 2005). Radiocarbon dates on Aleppo pine macro-remains show the presence of this species at the end of the 7th-millennium cal. BCE in Mesolithic contexts (García Puchol and Aura Tortosa 2006; Badal 2013), although there is a lack of direct dating for previous chronologies. In general, during the early Holocene, the remains of Aleppo pine are minor in relation to broadleaved species, among which Quercus plays a key role.

In Neolithic sequences from this area, an important presence of xeric and thermophilic species, among them Aleppo pine and the wild olive tree, is documented, especially at coastal sites, and has a somewhat minor presence in inland and mountain areas. From the 5th to 4th-millennium cal. BCE, Quercus forests seem to have reduced gradually as the formations of Aleppo pine, olive trees, strawberry trees, and scrubs increased in different studied sites, as a result of the settlement of Neolithic communities and the systematic use of fire (Badal and Roiron 1995; Badal 1990; Badal et al., 1994; Vernet et al., 1987). These dynamics intensified from $3000 \mathrm{cal}$. BCE onwards, with the expansion of pine forests, along with Fabaceae, Erica, Rosmarinus officinalis and Cistus understory (Badal 1990; Carrión Marco, 2003; Soler et al., 1999). In contrast, in some Neolithic II open air sites, the persistence of Quercus forests, showing a dynamic similar to that proposed above for northeastern Iberia, might be the result of a different exploitation of the land.

Finally, the recurrent use of Aleppo pine in the construction of Bronze and Iron Age villages in eastern Iberia shows the great availability and abundance of this species in the region (Mata and Bonet 1983; Grau Almero 1990; Bonet and Mata 2002; Carrión Marco and Grau Almero 2015). Hence, Aleppo pine must have survived in some enclaves during the Pleistocene and the early Holocene in eastern and southeastern Iberia, as it happened in the Ebro basin, from where it would have expanded afterwards. In coastal Neolithic sequences, its presence is observed earlier, while it expands later in sites located in meso-Mediterranean areas, suggesting a better adaptation to Mediterranean coastal environments. In this sense, against the general view of Aleppo pine as a mere intrusive component of a successional community, the native character of this species is claimed based on paleobotanical data for some southern or arid areas of Mediterranean Iberia (Badal 1998).

Based on the anthracological and paleoenvironmental data from neighbouring Iberia, it seems clear that Aleppo pine is a native tree and has been present in the regions since the Pleistocene. Furthermore, it presented an important development during Mesolithic, prior to the occurrence of potentially relevant anthropogenic landscape disturbances during the Neolithic, Bronze and Iron Ages. The parallel trends of Aleppo pine and other xeric and thermophyllous shrubby taxa also suggest that the spread of these species during prehistoric times would have been the result of climatic instability and increasing aridity and seasonality, and, in some regions, no clear evidence of broadleaved forest substitutions after anthropogenic disturbances has been found. However, in others sites (those with long-term occupations) the use of fire and human activity seem to be responsible for the rapid expansion of pine forests and the associated understory. These specific trends in Mediterranean Iberia, therefore, appear to be differentiated dynamics in relation to other continental regions in temperate Europe, where such kind of vegetation substitutions seem to be documented in paleoenvironmental records (Carrión et al., 2010). Hence, the development of Aleppo pine seems to be parallel to a process of the increasing shrubby character of the vegetation during the Holocene, linked to a north-south gradient of increasing climate aridity and seasonality, especially relevant in the coastal areas (Burjachs et al., 2000; Carrión et al., 2010).

In this context, the archaeobotanical and paleoenvironmental data from the island of Mallorca allow for a discussion of the role of Aleppo pine in this insular ecosystem. The KF14 marine sequence shows the continuous presence of pine pollen since the Upper Pleistocene and during all of the Holocene (Yll et al., 1999; Roure Nolla et al., 1995; Pérez-Obiol et al., 2000). In the Holocene coastal paleoenvironmental records in all the Balearic Islands, pine is also present throughout the sequence. In Mallorca and Menorca, an Early Holocene decrease in pine is detected in favour of the development of messic taxa (e.g., Buxus, Corylus and deciduous Quercus) and coastal formations of Juniperus and Ephedra (Yll et al., 1997; Burjachs et al. 1994, 2017; Pérez-Obiol et al. 2000, 2001; Servera-Vives et al., 2018). This has been interpreted as a result of wetter-than-today conditions in a context where human action was absent or scarce until at least the 5th or 4th millennium cal BP, when major vegetation changes occurred. Macchia-like vegetation, such as Olea, Pistacia and Erica, broadly developed in detriment to the messic taxa, forming the typical thermo- and meso-Mediterranean vegetation that has characterised the insular vegetation since then (Burjachs et al., 2017; Yll et al., 1999; Servera-Vives et al., 2018). The establishment of this new vegetal landscape across the archipelago has been interpreted as the result of the development of drier and more seasonal climatic conditions and a resilient human-climate-environmental relationship during the first centuries of prehistoric human occupation of the archipelago (Burjachs et al., 2017; Servera-Vives et al., 2018).

Archaeopalynological data from Mallorca show how the territories surrounding Bronze and Iron Age human settlements were characterised by an open landscape with a mosaic structure containing macchia-like forests, crop fields, and pasturelands (Mercuri et al., 2019; Servera-Vives and Picornell-Gelabert, 2018). Significant values of pine are not detected in any case, and this tree is even absent in some of the archaeological samples (Fig. 4). Pine pollen values are low or moderate ( $<40 \%$ in almost all cases) in coastal paleoenvironmental sequences in Mallorca and Menorca, with an increase in pine communities between ca. 3000-2000 cal. BC, as reported in the s'Albufera d'Alcúdia sequence (Burjachs et al., 2017; Kaniewski et al., 2020), also coinciding with drier climate conditions. Therefore, considering the high pollen productivity of pines (e.g., Heim 1970), the relatively low values in many 
archaeological samples, and its low to moderate values in littoral sequences, it can be suggested that the regional presence of pine is well attested by both palynological and archaeopalynological data, although they not seem to be as extensive as they are in the current landscape of the island. Otherwise, better development of pine woodlands seems to be attested in the southern Pitiüses islands (Eivissa and Formentera) as it happened on the southeastern coast of Iberia, proposing that such species would have increased development towards the southern territories (Burjachs et al., 2017).

Pine pollen values present a moderate increase at c. $3000 \mathrm{cal}$ BCE in s'Albufera d'Alcúdia, with values between c. $15 \%$ and 40\% (Burjachs et al. 1994, 2017; Kaniewski et al., 2020), coinciding with the Chalcolithic-Bronze Age transition. This slight increase in pine pollen is parallel to the increase of other xeric and thermophilic trees, such as wild Olea and Quercus. This fact probably reflects an increase in the tree cover on this part of the coast, related to a retreat of microregional human activities, as attested by the decline of ruderal taxa. While pine pollen expansion probably reflects the substitution of the former littoral juniper formations by pine communities, the evergreen Quercus' expansion probably reflects the regional expansion of these taxa in the Serra de Tramuntana mountains. It is around this time that the first archaeopalynological data are available for the Bronze Age sites of the Llevant region (Figura 4). Pine pollen values are again significantly minor in archaeological samples than in the coastal sequence of s'Albufera d'Alcúdia, and more significant values are detected at sites closer to the coast (e.g., Mestre Ramon and Ferradura, Fig. 1). In the central plain, pine pollen values are especially low during the Iron Age, with contexts where pine pollen is absent (Cas Canar). Higher values are detected in the western coastal sites of the Tramuntana region during this same period, thus reinforcing the idea that at the beginning of the Late Holocene, pines were relevant only in coastal areas.

The increased archaeopalynological values of pine appear to be parallel to that of xeric and sub-xeric shrubs. This is especially relevant in the Llevant and Tramuntana regions, where pine values are more significant (Fig. 4). Such xeric shrubs constitute the undergrowth of pine woodlands in Mallorca (Llorens et al., 2007). Accordingly, the parallel trends of pine and xeric shrubs suggests that their increase would represent an increase in forests around the sites, well adapted to both human and climatic agents. This parallel development of pine and xeric shrubs is also visible in the anthracological assemblages, especially in the Llevant and Tramuntana regions (Fig. 2). In neighbouring continental areas (Iberia), the development of pine and xeric shrub formations, to the detriment of broadleaved forests, has also been detected at the beginning of the Late Holocene, which, as commented before, has been attributed to an increase in climatic instability (i.e., aridity and seasonality; Allue et al., 2017; Aranbarri et al., 2020; Carrión et al., 2010). Moreover, in the Ebro basin and along the eastern and southeastern coast, it has also been highlighted that both timber and firewood demands related not only domestic energy consumption but also pottery and metal production would have represented an increase in wood exploitation during the Bronze and Iron Ages. In this context, pine would have been an especially targeted wood resource, so human activity is suggested to be more of a constraint than a promoter of pine tree development (Aranbarri et al., 2020).

In this line, pinewood exploitation has been proved to be irregular during prehistory in Mallorca. As discussed previously, pine is not generally considered to have been a relevant firewood resource during the BA. However, its use as firewood, timber and raw material increased significantly during the IA, especially in the LIA. This is notably relevant in the central plain, where the important use of pine firewood and timber is parallel to low, and even absent, pine pollen values, indicating that this tree would be a resource located far from the sites. The cutting down of pine trees is also documented in the central plain and in the Llevant. In this second region, it is relevant to detecting the cutting of pine trees to provide firewood for metallurgical activities at Ses Païsses (Picornell-Gelabert et al., 2020). Altogether, the anthracological and dendro-anthracological data suggest that Aleppo pine became a resource targeted by IA settlers of Mallorca.

Accordingly, the available archaeobotanical and palaeoenvironmental records in Mallorca seem to clearly reflect that Aleppo pine represents a local, natural species throughout the Holocene. The development of pine woodlands does not appear to be relevant during the first two millennia of permanent human occupation of the island according to Late Holocene palynological and anthracological evidence. The development of pine woodlands seems to be rather limited, probably only in coastal areas. This development of pine is parallel to the development of other xeric and sub-xeric taxa, indicating that these taxa were better adapted to Late Holocene climatic conditions of increasing instability, aridity and seasonality. In fact, the relevant shift on the vegetation landscape of the archipelago appears to have occurred prior or parallel to the first human occupation of the islands, when macchia formations broadly developed at the expense of an abrupt decrease in messic taxa (Burjachs et al., 2017; Servera-Vives et al., 2018).

Altogether, then, the development of pine woodlands between c. 2300 cal. BCE and the 1st century ACE does not appear to have been the result of the substitution of other vegetation formations after anthropogenic landscape transformation. Aleppo pine is especially adapted to the main constraints of Mediterranean environments, such as climatic instability and seasonality, drought, and disadvantageous edaphic conditions. This seems to be the reason its development was especially focused in coastal areas during this period. In this sense, anthracological studies have not shown an over-exploitation of Juniperus and Ephedra coastal formations, reported to have been important in previous, more humid climatic conditions according to paleoenvironmental records (Burjachs et al., 2017), resulting in the spread of pines in these areas. Hence, this substitution seems to be explained by climatic and ecological agents rather than anthropogenic action.

Therefore, a relevant development of Aleppo pine woodlands on the island after human landscape transformation during prehistory and protohistory does not seem to have been detected. Such anthropogenic landscape transformation processes resulting in the spread of pine species would develop in later periods, sometime after the Romanisation of the islands or during historical times. However, the lack of archaeobotanical data for historical periods makes it impossible to further define the nature and chronology of such processes, while it has been possible for neighbouring regions (Aranbarri et al., 2020). The well-dated palynological sequence of s'Albufera des Grau (Burjachs et al., 2017) records the expansion of pine formations after the Christian conquest of Menorca in the 13th century. In the case of Mallorca, the sequence of Santa Ponça (Parra, 1994) also shows the expansion of pinewoods in the upper part of the diagram, with no reliable chronology ascribed. However, high-resolution paleoenvironmental and archaeobotanical studies are still needed to precisely trace pine species in the Balearics over the past 2000 years.

As stated previously, pinewood formations in Mallorca increased dramatically during the latter half of the previous century due to dramatic changes in land use. Indeed, according to the phytosociological idea of unfixed floristics of pinewood communities in Mallorca, they occupy a quite broad range of ecological conditions. The prospect of future increases in aridity and seasonality due to climate change would be a limitation for most of the broadleaves species to spread throughout the archipelago. Considering the broad versatility of Pinus halepensis to phytoclimatic characteristics and edaphic conditions, increased aridity would severely affect this species only in the extremes of its area of suitability (Cámara, 2001), but there are some indications of severe impacts and decay due to heavy drought episodes (Esteve et al., 2007). In Balearic vegetation, such climatic changes should favour the maintenance of paraclimacic communities, as macchia or garrigues of xeric shrubs cover a broad area of the island, both coastal and inland, where Pinus halepensis could play a dominant role. 


\section{Conclusions}

Aleppo pine is a dominant species in all current tree-covered vegetation formations on the island of Mallorca, with the only exception being oak forests (Quercus ilex L.) and riparian forests. Pine-dominated woodlands represent the most widespread forest formations in the Balearic archipelago (IFN 2012). Ecological and reproductive studies suggest that this is because of its ecological plasticity and rapid post-fire regeneration due to serotony (Goubitz et al., 2003), a characteristic that also improves its adaptation to climatic (especially drought) and edaphic constraints in Mediterranean environments (Ne'eman et al., 2004). These traits could explain the pioneering role and spread of Aleppo pine woodlands after major anthropogenic landscape transformations, especially in areas suitable for the development of sclerophyllous vegetal formations in which it would have been rare or scarce (Bolòs 1993; Gil et al., 2003). This Aleppo pine expansion has been especially relevant since the mid-20th century, when the massive abandonment of former agricultural and pastoral lands led to a crucial process of landscape transformation in the Balearics, as well as in many other parts of the Mediterranean basin (Grove and Rackham 2003).

The study of the role of Aleppo pine woodlands at the beginning of the Late Holocene becomes a relevant subject when evaluating the nature of the presence of this tree in the Balearics and the role of human action regarding its distribution during the first two millennia of permanent human occupation of the island. As in many Mediterranean environments, the use of archaeobotanical data becomes a relevant proxy for paleobotanical studies, as inland lakes, peat bogs and other reliable paleoenvironmental records are not available. In this sense, anthracological, dendro-anthracological and archaeopalynological data from the Chalcolithic, Bronze and Iron Age, along with available off-site paleoenvironmental sequences, allow us to evaluate the spread of Aleppo pine woodlands on the island and the role of human action in relation to it.

It seems clear that Aleppo pine constitutes a natural species of the Holocene vegetation of Mallorca, as is the case for other islands of the archipelago. However, according to the archaeobotanical data, it seems clear that the spread of pine woodlands would be more constrained than it is today and better developed in coastal areas. There is no evidence of the spread of pine-dominated woodlands on Mallorca during prehistory and protohistory as a consequence of the substitution of other forest formations due to human action. It should be taken into account that during these periods, there was an increase or decrease in parallel with pine of other xeric, sclerophyllous and thermophilic taxa, especially shrubs, which would be especially favoured by Late Holocene climatic conditions on the island.

The use of pine as firewood and timber appears to have been minor during the Bronze Age. However, its use increased during the IA, especially the LIA, when pines were especially targeted to fuel domestic, ritual and metallurgical fires, as well as used as construction timber. In these last moments of prehistory, the increasing exploitation of pines could be explained by the fact that in a context of increasing fuel demands, this would be a common and available tree of a relevant height, along with wild olive trees. Although pines are not self-pruning trees (Ne'eman et al., 2004), they produce an important amount of deadwood (IFN 2012), which could also be related to its increasing use as firewood. Moreover, wild olive is the most used tree for construction timber, followed by pine (Dufraisse et al., 2018Dufraisse et al., 2018), thus indicating selective exploitation of the woody vegetation according to specific demands. Hence, when timber and firewood demand increased during the EIA and, especially during the LIA, cutting down pines by human groups occurred, as shown by dendro-anthracological data. However, the archaeobotanical records do not suggest that this increasing forest resource exploitation resulted in a human-induced spread of Aleppo pine on the island. Such processes, which are well attested in the current vegetation landscape of Mallorca, would have begun sometime after the Romanisation of the island.

\section{Declaration of competing interest}

The authors declare that they have no known competing financial interests or personal relationships that could have appeared to influence the work reported in this paper.

\section{Acknowledgements}

This study was supported by the Spanish Ministry of Science, Innovation and Universities (the work of LPG -IJCI-2015-24550- and GSV -IJCI-2016-30581- was founded by Juan de la Cierva-Incorporación fellowships), the Spanish Ministry of Economy, Industry and Competitiveness (projects HAR2015-67211-P, PID2019-108692 GB-I00 and HAR2017-83656P), and by the Direcció General de Innovació i Recerca of the Government of the Balearic Islands (project PRD2018/19). Andrés Currás was funded by the Galician Innovation Agency (GAIN).

We are grateful to Alejandra Galmés (UIB) for drawing Fig. 1 and to the archaeologists responsible for excavating the studied sites and providing samples in support of archaeobotanical research.

\section{References}

Alcover, J.A., 2008. The first Mallorcans: prehistoric colonization in the western Mediterranean. J. World Prehist, 21, 19-84.

Allué, E., Euba, I., Picornell, Ll, Solé, A., 2013. Perspectivas teóricas y metodológicas en antracología para el estudio de las relaciones entre las sociedades humanas y su entorno. Arkeogazte 3, 27-49.

Allue, E., Picornell-Gelabert, Ll, Daura, J., Sanz, M., 2017. Reconstruction of the palaeoenvironment and anthropogenic activity from the upper Pleistocene/ Holocene anthracological records of the NE Iberian Peninsula (Barcelona, Spain). Quat. Int. 457, 172-189.

Aranbarri, J., Alcolea, M., Badal, E., Vila, S., Allué, E., Iriarte-Chiapusso, M.J. Sebastián, M., Magri, D., González-Sampériz, P., 2020. Holocene history of Aleppo pine (Pinus halepensis Mill.) woodlands in the Ebro basin (NE Spain): climate-biased or human-induced? Rev. Palaeobot. Palynol. 279, e104240.

Aramburu, J., 2009. Ses Païsses (Artà, Mallorca). Excavaciones en el Edificio 25 (“Climent Garau”). Campañas 2004, 2005 y 2006 Author's edition, Palma. https://www.academia.edu/20195097/Ses_Pa\%C3\%AFsses_Art\%C3\%A0 Mallorca_Excavaciones_en el_edificio 25.

Aura, E., Carrión, Y., Estrelles, E., Pérez Jordà, G., 2005. Plant economy of huntergatherer groups at the end of the last Ice Age: plant macroremains from the cave of Santa Maira (Alacant, Spain) ca. 12000-9000 BP. Veg. Hist. Archaeobotany 14 (4), $542-550$.

Badal, E., 1990. Aportaciones de la antracología al estudio del paisaje vegetal y su evolución en el Cuaternario reciente, en la costa mediterránea del País Valenciano y Andalucía (18.000-3.000 BP). PhD thesis, Universitat de València.

Badal, E., 1998. El interés económico del pino piñonero para los habitantes de la Cueva de Nerja. In: Sanchidrián, Simón (Ed.), Las culturas del Pleistoceno superior en Anadalucía. Patronato de la cueva de Nerja, Sevilla, pp. 287-300.

Badal, E., 2013. Los usos de los vegetales leñosos en el Cabezo de la Cruz (La Muela, Zaragoza) durante la ocupación mesolítica. In Rodanés Vicente, J.M ${ }^{\mathrm{a}}$. In: Picazo Millán, J.V. (Ed.), El campamento mesolítico del Cabezo de la Cruz La Muela. Zaragoza. Monografías Arqueológicas. Prehistoria, 45. Prensa de la Universidad de Zaragoza, Zaragoza, pp. 83-99.

Badal, E., Bernabeu, J., Vernet, J.L., 1994. Vegetation changes and human action from the Neolithic to the Bronze Age (7000-4000 BP) in Alicante, Spain, based on charcoal analysis. Veg. Hist. Archaeobotany 3, 155-166.

Badal, E., Roiron, P., 1995. La Prehistoria de la vegetación en la península Ibérica. Saguntum 28, 29-48.

Barbéro, M., Loisel, R., Quézel, P., Richardson, D.M., Romane, F., 1998. Pines of the Mediterranean basin. In: Richardson, D.M. (Ed.), Ecology and Biogeography of Pinus. Cambridge University Press, Cambridge, pp. 153-170.

Bellot, F., 1978. El tapiz vegetal de la Península Ibérica. H. Blume, Madrid.

Berbiela, L., 2015. La puesta en valor de los pinos y los pinares de Mallorca: una necesidad ambiental y un reto social. In J. Oliver, A, Alemany (Coord.). El llibre verd de protecció d'espècies a les Balears. Monografies de la Societat d'Història Natural de les Balears, 20. Palma de Mallorca 467-485.

Beug, H.-J., 2004. Leitfaden der Pollenbestimmung für Mitteleuropa und angrenzende Gebiet. Pfeil, München.

Bolòs, Oriol de, 1993. La funció dels pins en el paisatge dels Països Catalans. Treballs de la Societat Catalana de Geografia 35, 17-23.

Bonet, H., Mata, C., 2002. El Puntal dels Llops: un fortín edetano. Serie de Trabajos Varios 99. Diputación de Valencia. Valencia.

Braun-Blanquet, J., Bolós, O., 1987. Las Comunidades Vegetales de la Depresión del Ebro y su Dinamismo. Ayuntamiento de Zaragoza, Zaragoza.

Burjachs, F., 2005. Informe de l'análisi palinológica del jaciment arqueológico de Ses Païsses (Artá Mallorca, Illes Balears). In: Aramburu, J., Hernández, J. (Eds.), Memoria de las excavaciones arqueológicas en el poblado talayótico de Ses Païsses (Artà, Mallorca). Campañas 1999-2000. Arqueobalear, Palma de Mallorca). 
Burjachs, F., Pérez-Obiol, R., Roure, J.M., y Julià, R., 1994. Dinámica de la vegetación durante el Holocenos en la isla de Mallorca. In Collective volum, Trabajos de palinología básica y aplicada, X Simposio de Palinologia (APLE). Valencia: Universitat de València 199-210.

Burjachs, F., Giralt, S., Roca, J.R., Seret, G., Julià, R., 1997. Palinología holocénica y desertización en el Mediterráneo Occidental. In: Ibáñez, J.J., Valero, B.L., Machado, C. (Eds.), El paisaje mediterráneo a través del espacio y del tiempo. Implicaciones en la desertificación. Ed. Geoforma, Logroño, pp. 379-394.

Burjachs, F., Blech, M., Marzoli, D., Julià, R., 2000. Evolución del paisaje en relación con el uso del territorio en la edad del hierro en el NE de la península Ibérica. In: Buxó, R., Pons, E. (Eds.), Els productes alimentaris d'origen vegetal a l'Edat del Ferro de l’Europa Occidental: de la producció al consum. Sèrie Monográfica 18. Museu Arqueològic de Catalunya, pp. 31-42. Girona.

Burjachs, F., López Sáez, J.A., Iriarte, M.J., 2003. Metodología arqueopalinológica. In: Buxó, R., Piqué, R. (Eds.), La recogida de muestras en arqueobotánica: objetivos y propuestas metodológicas. Museu d'Arqueologia de Catalunya, Barcelona, pp. 11-18.

Calvo, M., 2009. Reflexiones en torno a los esquemas de racionalidad espacial reflejados en el paisaje durante la prehistoria de Mallorca. Pyrenae 40 (2), 37-78.

Calvo, M., Guerrero, V., Salvà, B., 2002. Los orígenes del poblamiento balear. Una discusión no acabada. Complutum 13, 159-1191.

Calvo, M., Guerrero, V., 2002. Los inicios de la metalúrgia en Baleares: el calcolítico (c. 2500-1700 cal. BC). Palma, El Tall Editor.

1 Calvo, M., Van Strydonck, M.aPicornell-Gelabert, Ll, Boudin, M., Albero Santacreu, D. Coll Sabater, M., Garcia Rosselló, J., 2020. Dying in the Hallstatt plateau: the case of wooden coffins from Iron Age necropolises in Mallorca (Balearic islands, western Mediterranean) and the difficulties in defining their chronology. Archaeological and Anrthropological Sciences 12(10) 247. https://doi.org/10.1007/s12520-020-01206-

Cámara, A., 2001. Comportamiento del pino carrasco (Pinus halepensis Miller) frente a las variaciones climáticas. In J.F. Mota Poveda, F. Gómez Mercado (Coords.) Vegetación y cambio climático. In: Universidad de Almería, Almería (Eds.), pp. 37-46.

Carrión, J.S., Fernández, S., 2009. The survival of the 'natural potential vegetation' concept (or the power of tradition). J. Biogeogr. 36 (12), 2202-2203.

Carrión, J.S., Fernández, S., González-Sampériz, P., Gil-Romea, G., Badal, E., CarriónMarco, Y., López-Merino, L., López- Sáez, J.A., Fierro, E., Burjachs, F., 2010. Expected trends and surprises in the lateglacial and Holocene vegetation history of the Iberian Peninsula and Balearic islands. Rev. Palaeobot. Palynol. 162 (3), 458-475.

Carrión Marco, Y., 2003. Afinidades y diferencias de las secuencias antracológicas en las vertientes mediterránea y atlántica de la península Ibérica. PhD thesis. Universitat de València.

Carrión Marco, Y., Grau Almero, E., 2015. Madera y leña en la Lloma de Betxí. In De Pedro Michó, M ${ }^{\mathrm{a}}$.J. In: Soler Mayor, B. (Coords) (Ed.), Vivir junto al Turia hace 4000 años. La Lloma de Betxí, pp, 62-67. Museo de Prehistoria de Valencia, Diputación Provincial de Valencia, Valencia.

Carrión Marco, Y., Picornell Gelabert, Ll, Dufraisse, A., Martín Gordon, R., Argüello, J. 2019. Wood management in the ceremonial building of the Na Galera islet (Balearic Islands, Western Mediterranean): fuel, timber and coastal vegetation at the end of the first millennium BC. In: Asouti, E. (Ed.), anthraco2019-7th International Anthracology Meeting "Charcoal Science in Archaeology and Palaeoecology" (Liverpool, 2-6 September 2019). Conference Programe \& Abstracts Volume. Department of Archaeology, Classics and Egyptology, University of Liverpool, pp. 55-56.

Cao, X.Y., Tian, F., Xu, Q.H., Li, Y.C., Zhang, J.Q., Jia, H.J., Zhang, L.Y., Wang, X.L., 2007. Pollen influx and comparison with surface pollen in the east part of Yinshan Mountains. Acta Palaeontol. Sin. 46 (4), 411-419 (in Chinese with English abstract).

Costa, M., 1987. El País Valenciano. In: Peinado, M., Rivas Martínez, S. (Eds.), La Vegetación de España. Servicio de Publicaciones de la Universidad de Alcalá, pp. 281-308. Madrid.

Coubray, S., Dufraisse, A., 2019. De l'arbre à la forêt domestiquée : pratiques de gestion et systèmes agroforestiers. Application de l'anthraco-typologie sur des sites néolithiques du Nord de la France et du pourtour de l'arc alpin. In: Montoya, C., Fagnart, J.-P., Locht (Dir), J.-L. (Eds.), Préhistoire de l'Europe du Nord-Ouest. Mobilités, climats et identités culturelles, actes du 27e congrès préhistorique de France (Amiens, 30 mai-4 juin 2016), vol. 3. Société préhistorique française, Paris, pp. 139-159.

Daskalakou, E.N., Thanos, C.A., 1996. Aleppo pine (Pinus halepensis) postfire regeneration: the role of canopy and soil seed banks. Int. J. Wildland Fire 6, 59-66.

Dufraisse, A., Coubray, S., Girardclos, O., Nocus, N., Lemoine, M., Dupouey, J.-L., Marguerie, D., 2018. Anthraco-typology as a key approach to past firewood exploitation and woodland management reconstructions. Dendrological reference dataset modelling with dendro-anthracological tools. Quat. Int. 463 (Part B), 232-249.

Ejarque, A., Miras, Y., Riera, S., 2011. Pollen and non-pollen palynomorphs indicators of vegetation and highland grazing activities obtained from modern surface and dung datasets in the eastern Pyrenees. Rev. Palaeobot. Palynol. 167, 123-139.

Esteve, M.A., Carreño, M.F., Moya, J.M., Montoya, P., Martínez, J., Lloret, F., 2007. La respuesta de los bosques de Pinus halepensis al cambio climático y los eventos de sequía extrema. In C. Conesa, P. Pérez (Coord.) Riesgos Ambientales en la Región de Murcia. Ediciones de la Universidad de Murcia. Murcia 1025-1033.

Faegri, K., Kaland, P.E., Krzywinski, K., 1989. Textbook of pollen analysis by knut faegri and johs. In: Iversen, I.V. (Ed.), John Wiley and Sons Ltd. Chichester.

Fall, P., 2012. Modern vegetation, pollen and climate relationships on the Mediterranean island of Cyprus. Rev. Palaeobot. Palynol. 185, 79-92.

Florenzano, A., Mercuri, A.M., Pederzoli, A., Torri, P., Bosi, G., Olmi, L., Rinaldi, R., Bandini Mazzanti, M., 2012. The significance of intestinal parasite remains in pollen samples from Mediaeval pits in the Piazza Garibaldi of Parma, Emilia-Romagna, Northern Italy. Geoarchaeology 27, 34-47.
Florenzano, A., Mercuri, A.M., Carter, J.C., 2013. Economy and environment of the Greek colonial system. In: Italy, Southern (Ed.), Pollen and Npps Evidence of Grazing from the Rural Site of Fattoria Fabrizio (6th - 4th Cent. Bc; Metaponto, Basilicata), vol. 3, pp. 173-181. Annali Di Botanica.

García Puchol, O., Aura Tortosa, J.E.(Coords), 2006. El abric de la Falguera (Alcoi, Alacant): 8.000 años de ocupación humana en la cabecera del río de Alcoi. Diputación de Alicante, Excmo. Ayuntamiento de Alcoy y Caja de Ahorros del Mediterráneo (Alcoi).

Gelabert-Oliver, M., Hernández-Gasch, J., Puig, A., 2018. Updating knowledge: architecture, use and chronology of the Late Bronze Age stepped monuments in Mallorca. Trab. Prehist. 75 (1), 128-145.

Gil, L., Manuel, C., Díaz, P., 2003. La transformación histórica del paisaje forestal en las islas Baleares. Ministerio de Medio Ambiente. Madrid.

Girard, M., Renault-Miskovsky, J., 1969. Nouvelles techniques de preparation en Palynologie appliques à trois sediments du Quaternaire final de l'Abri Cornille (Istres-Bouches du Rhone). Bulletin AFEQ 4, 275-284.

Goeury, C., de Beaulieu, J.-L., 1979. A propos de la concentration du pollen à l'aide de la liqueur de Thoulet dans les sediments minéraux. Pollen et Spores XXI (1-2) 239-251.

Goubitz, S., Werger, M., Ne'eman, G., 2003. Germination response to fire-related factors of seeds from non-serotinous and serotinous cones. Plant Ecol. 169, 195-204.

Grau Almero, E., 1990. El uso de la madera en yacimientos valencianos de la Edad del Bronce a época visigoda. PhD thesis. In: Datos etnobotánicos y reconstrucción ecológica según la antracología. Universitat de València.

Grove, A.T., Rackham, O., 2003. The Nature of Mediterranean Europe: an Ecological History. Yale University Press, New Haven, CT.

Guerrero, V.M., Calvo, M., Garcia, J., Gornés, S., 2007. Prehistoria de las Islas Baleares. Registro arqueológico y evolución social antes de la Edad del Hierro. British Archaeological Reports International Series, 1690. Oxford.

Guerrero, V., Calvo, M., 2008. Resolviendo incertidumbres. In: Hernández, M., Soler, J., López, J. (Eds.), Nuevos datos sobre las pri- meras ocupaciones humanas de las Baleares, pp. 331-339. IV Congreso el Neolítico Peninsular. Museo Arqueológico de Alicante, Alicante.

Heim, J., 1970. Les relations entre les spectres polliniques récents et la végétation actuelle en Europe occidentale. PhD thesis, Université de Louvain, Lovain.

Hernández-Gasch, J., Puig Palerm, A., Valenzuela Oliver, A., Picornell Gelabert, L 1, Servera-Vives, G., Vicens Siquier, M.A., Pérez-Jordà, G., 2020. Història d'una galeria: la plataforma esglaonada de Mestre Ramon (Son Servera, Mallorca) i el seu entorn biològic i cultural entre ca. s. XI i II ANE. In: Jordi, Hernández-Gasch, María, J., Rivas, Antequera, Margalida Rivas, Llompart (Eds.), VIII Jornades d'Arqueologia de les Illes Balears. Consell Insular de Mallorca, Palma, pp. 117-127.

IFN, 2012. Cuarto inventario forestal nacional: Illes Balears. In: Ministerio de Agricultura. Alimentación y Medio Ambiente, Madrid.

Juggins, S., 2007. C2 version 1.5 user guide. In: Software for Ecological and Palaeoecological Data Analysis and Visualisation. Newcastle University, Newcastle upon Tyne.

Kaniewski, D., Marriner, N., Cheddadic, R., Morhanged, C., Cau Ontiverose, M.A. Fornós, J., Giaimeg, M., Trichona, V., Ottoa, T., Lucea, F., Van Campo, E., 2020. Recent anthropogenic climate change exceeds the rate and magnitude of natural Holocene variability on the Balearic Islands. Anthropocene 32, 2213-3054. https:// doi.org/10.1016/j.ancene.2020.100268.

Llergo, Y., Riera, S., 2010. Informe polínico del yacimiento arqueológico Puig de sa Morisca. In: Technical Report, 27pp.

Llergo, Y., Riera Mora, S., 2010. Estudio polínico de muestras sedimentarias de los yacimientos arqueológicos de Ses Païses y Cascanar, (Mallorca, Islas Baleares). In: Technical Report. University of Barcelona, 16pp.

Llergo, Y., Servera-Vives, G., Riera Mora, S., 2010. Informe arqueopolínico del yacimiento arqueológico del Turó de ses Beies. In: Technical Report. University of Barcelona, 21pp.

Llorens, Ll, Gil, L., Tébar, F.J., 2007. La vegetació de l'illa de Mallorca. In: Bases per a la interpretació i gestió d'hàbitats. Associació Jardí Botànic de Palma, Palma.

Lull, V., Micó Pérez, R., Rihuete Herrada, C., Risch, R., 2004. Los cambios sociales en las Islas Baleares a lo largo del II milenio. Cypsela 15, 123-148.

Lull, V., Micó, R., Rihuete, C., Risch, R., 1999. Ideología y sociedad en la prehistoria de Menorca. La Cova des Càrritx y la Cova des Mussol. Consell Insular de Menorca, Barcelona.

Martínez del Castillo, E., Tejedor, E., Serrano-Notivoli, R., Novak, K., Saz, M.Á. Longares, L.A., de Luis, M., 2018. Contrasting Patterns of tree growth of Mediterranean pine species in the Iberian Peninsula. Forests 9, 416-431.

Mata, C., Bonet, H., 1983. Un nivel de la Edad del Bronce en el Puntal dels Llops (OlocauValencia). XVI Congreso Nacional de ArqueologíA, Zaragoza, pp. 249-258.

Menéndez-Amor, J., Florschütz, F., 1961. La concordancia entre la composición de la vegetación durante la segunda mitad del Holoceno en la costa de Levante (Castelló de la Plana) y la costa W. de Mallorca. Bol. R. Soc. Esp. Hist. Nat. (G) 59, 97-100.

Mercuri, A.M., Bandini Mazzanti, M., Torri, P., et al., 2012. A marine/terrestrial integration for mid late Holocene vegetation history and the development of the cultural landscape in the Po Valley as a result of human impact and climate change. Veg. Hist. Archaeobotany 21, 353-372.

Mercuri, A.M., Florenzano, A., Burjachs, F., Giardini, M., Kouli, K., Masi, A., PicornellGelabert, Ll, Revelles, J., Sadori, L., Servera-Vives, G., Torri, P., Fyfe, R., 2019. From influence to impact: the multifunctional land use in Mediterranean prehistory emerging from palynology of archaeological sites (8.0-2.8 ka BP). Holocene 29 (5), $830-846$.

Micó, R., 2006. Radiocarbon dating and Balearic prehistory. Reviewing the Periodization of the prehistoric sequence. Radiocarbon 48 (3), 421-434. 
Miras, Y., 2009. L'étude des relations entre végétation et pluie pollinique actuelle sur le plateau de Millevaches (Limousin, France): outil pour une meilleure caractérisation pollenanalytique des formes paysagères et des practiques agrosylvopastorales. Rev. Sci. Nat. Auvergne 73, 71-104.

Moore, P., Webb, J., Collinson, M., 1991. Pollen Analysis, second ed. Oxford University Press, Oxford.

Ne'eman, G., Trabaud, L. (Eds.), 2000. Ecology, Biogeography and Management of Pinus Halepensis and P. Brutia for Estecosystems in the Mediterranean Basin. Backhuys Publishers, Leiden.

Ne'eman, G., Goubitz, S., Nathan, R., 2004. Reproductive traits of Pinus halepensis in the light of fire - a critical review. Plant Ecol. 171, 69-79.

Ne'eman, G., Izhaki, I., 2006. Stability of pre- and post-fire spatial structure of pine trees in Aleppo pine forest. Ecography 21, 535-542.

Parra, I., 1994. Quantification des precipitations à partir des espectres polliniques actuels et fossils: du Tardiglaciaire à l'Holocène supérieur de la côte méditerranéenne espagnole. PhD thesis. Université Montpellier II.

Pausas, J.G., Ouadah, N., Ferran, A., Gimeno, T., Vallejo, R., 2002. Fire severity and seedling establishment in Pinus halepensis woodlands, eastern Iberian Peninsula. Plant Ecol. 169, 205-213.

Pausas, J.G., Ribeiro, E., Vallejo, R., 2004. Post-fire regeneration variability of Pinus halepensis in the eastern Iberian Peninsula. For. Ecol. Manag 203, 251-259.

Peinado Lorca, M., 1987. La vegetación de España. In: Rivas-Martínez, S. (Ed.). Universidad de Alcalá de Henares, Alcalá de Henares.

Pérez-Jordà, G., Peña-Chocarro, L., Picornell-Gelabert, Ll, Carrión-Marco, Y., 2018. Agriculture between the third and the first millennium BC in the Balearic Islands: the archaeobotanical data. Veg. Hist. Archaeobotany 27 (1), 253-265.

Pérez-Obiol, R., Yll, E., Pantaleon-Cano, J., Roure, J.M., 2000. Evaluación de los impactos antrópicos y los cambios climáticos en el paisaje vegetal de las Islas Baleares durante los últimos 8000 años. In: Guerrero, V., Gornés, S. (Eds.), Colonización humana en ambientes insulares. Interacción con el medio y adaptación cultural. Universitat de les Illes Balears, Palma, pp. 73-98.

Pérez-Obiol, R., Yll, E.I., Pantaleón-Cano, J., Roure, J.M., 2001. Canvis en el paisatge vegetal de les Illes Balears durant el final del Quatemarí. Monogr. Soc. Hist. Nat. les Balears 9, 69-89.

Picornell Gelabert, L 1, Servera Vives, G., 2017. Landscape practices and everyday life in domestic spaces in Bronze Age Mallorca (Balearic islands): Perspectives for and archaeology of fuel and firewood. Quat. Int. 431, 73-89.

Picornell-Gelabert, Ll, 2012. Paisaje vegetal y sociedades prehistóricas y protohistóricas en Mallorca y Menorca: Una aproximación desde la antracología. PhD thesis. Universitat de Barcelona.

Picornell Gelabert, L 1, Carrión Marco, Y., 2017. Landscape and firewood procurement at the prehistoric and protohistoric site of ses Païsses (island of Mallorca, western Mediterranean). Quat. Int. 458, 56-74.

Picornell-Gelabert, Ll, Calvo, M., Garcia, J., Servera, G., Bosi, G., Nadal, J., Riera, S., Allué, E., 2018b. Towards an archaeology of the social meanings of the environment: plants and animals at the Son Ferrer prehistoric ceremonial and funerary staggered turriform (Mallorca, Balearic Islands). In: Livarda, A., Madgwick, R., Riera, S. (Eds.), The Bioarchaeology of Ritual and Religion. Oxbow, London, pp. 148-168.

Picornell-Gelabert, Ll, Servera-Vives, G., 2019. Paisatge vegetal i el seu aprofitament. E paisatge vegetal de l'illa de Menorca i l'aprofitament dels recursos vegetals (Sa Ferradura). In: Anglada, M. (Ed.), Promontoris i murades. Els assentaments costaners de l'Edat del Bronze a Mallorca i Menorca, pp. 63-66. Museu de Ciutadella, Ciutadella.

Picornell-Gelabert, Ll, Dufraisse, A., 2018. Wood for building: woodland exploitation for timber procurement in the prehistoric and protohistoric Balearic islands (Mallorca and Menorca; western Mediterranean). Environ. Archaeol. https://doi.org/10.1 080/14614103.2018.1521086.

Picornell-Gelabert, Ll, Dufraisse, A., de Luís, M., Mus Amézquita, M., Carrión Marco, Y. 2020. Modelling dendro-anthracological parameters with dendrochronological reference datasets: interrogating the applicability of anthraco-typology to assess Aleppo pine (Pinus halepensis Miller) wood management from archaeological charcoal fragments. J. Archaeol. Sci. 124 https://doi.org/10.1016/j. jas.2020.105265, 105265

Piqué, R., Noguera, M., 2002. Landscape and management of forest resources in the Balearic Islands during the II-I millennium BC. In: Waldren, W., Ensenyat, J. (Eds.), World Islands in Prehistory. International Insular Investigations. British Aarchaeological Reports Int. Ser., Oxford, pp. 292-300.

Piqué, R., Noguera, M., 2003. La gestión de los recursos forestales durante la prehistoria de las Islas Baleares: el yacimiento del Puig Morter de Son Ferragut. In: Castro, P., Escoriza, T., Sanahuja, M.E. (Eds.), Mujeres y hombres en espacios domésticos. Trabajo y vida social en Mallorca (c. 700-500 cal ANE). El Edificio Alfa del Puig Morter de Son Ferragut (Sineu, Mallorca). British Aarchaeological Reports Int. Ser. Oxford, pp. 322-332.

Punt, W., Blackmore, S., Hoen, P., Stafford, P. (Eds.), 1976-2009. The Northwest European Pollen Flora, Vol vols. I-IX., Elsevier, Amsterdam.
Quézel, P., Barbero, M., 1990. Les fore^ts méditerranéennes. Problèmes posés par leursignification historique, écologique et leur conservation. Acta Bot. Malacit 15, $145-178$.

Quézel, P., Barbero, M., 1992. Le pin d'Alep et les espèces voisines: répartition et caractères écologiques généraux, sa dynamique récente en France méditerranéenne. Forêt méditerranéenne 13, 158-170.

Räsänen, S., Suutari, H., Nielsen, A.B., 2007. A step further towards quantitative reconstruction of past vegetation in Fennoscandian boreal forests: pollen productivity estimates for six dominant taxa. Rev. Palaeobot. Palynol. 146, 208-220.

Ramis, D., 2018. Animal exploitation in the early prehistory of the Balearic islands. J. I. Coast Archaeol. 13 (2), 296-282.

Reille, M., 1992-!995. Pollen et spores d'Europe et d'Afrique du Nord. Atlas photographique. Laboratoire de Botanique Historique et Palynologie, URA 1152/ CNRS, Marseille.

Rivas Martínez, S., 1987. Memoria del Mapa de Series de Vegetación de España. In: ICONA. Ministerio de Agricultura. Pesca y Alimentación, Madrid.

Rivas-Martínez, S., Costa, M., Soriano, P., Pérez, R., Llorens, Ll, Rosselló, J.A., 1992. Datos sobre el paisaje vegetal de Mallorca e Ibiza (Islas Baleares, España) VII Excursión Internacional de Fitosociología (AEFA). Itinera Geobot. 6, 5-98.

Rosselló, V.M., Fornós, J.J., Gómez-Pujol, L. (Eds.), 2003. Introducción a la Geogra física de Menorca. AGE-Universitat de València-Universitat de les Illes Balears-Societat d'Història Natural de les Balears. Palma.

Ros, M.T., 1984. Análisis antracológico del poblado tala- yótico de Son Fornés (Mallorca). In: Gasull, P., Lull, V., Sanahuja, M.E. (Eds.), Son Fornés I: La Fase Talayótica. British Aarchaeological Reports Int. Ser, Oxford, pp. 136-137, 209.

Roure Nolla, J.M., Pérez-Obiol, R., Belmonte Soler, J., Yll, E., Cano, J-I., 1995. In: Palynological Study on Desertification in South-Western Europe: Timing, Natural Trends and Human Impact. Spain. Final Report on Contract EV5V-CT91-0027, EU. Brussels.

Servera-Vives, G., Currás, A., 2016a. Informe arqueopol-línic de s'Hospitalet Vell (Manacor). In: Technical Report, $12 \mathrm{pp.}$

Servera-Vives, G., Currás, A., 2016b. Informe arqueopol-línic de Son Serra (Muro) technical report, 10p.

Servera-Vives, G., Currás, A., 2017a. Informe arqueopol-línic de Mestre Ramon (Son Servera. Technical report, $18 \mathrm{p}$.

Servera-Vives, G., Currás, A., 2017b. Informe arqueopol-línic de Sa Ferradura (Manacor). Technical report, $9 \mathrm{p}$

Servera-Vives, G., Riera, S., Picornell-Gelabert, L., et al., 2018. The onset of islandscapes in the Balearic islands: a study-case of Addaia (northern Menorca, Spain). Palaeogeography, Palaeoclimatology,. Palaeoecology 498 (1), 9-23.

Servera Vives, G., Picornell Gelabert, L 1, 2018. Reconstruction of mosaic landscapes in the Balearic islands, western Mediterranean. In: In 2018 IEEE International Workshop on Metrology for Archaeology and Cultural Heritage (MetroArchaeo 2018) Proceedings, Cassino.

Sintes, E., 2015. Guia Menorca Talaiòtica. In: La prehistòria de l'Illa. Triangle Books, Barcelona.

Soler, J.A., Dupré, M., Ferrer, C., González-Sampériz, P., Grau, E., Máñez, S., Roca de Togores, C., 1999. Cova d'En Pardo, Planes, Alicante. In: Primeros resultados de una investigación pluridisciplinar en un yacimiento prehistórico. Geoarqueología i Quaternari litoral. Memorial Maria Pilar Fumanal, Universitat de València, València, pp. 269-281.

Sureda-Negre, J., Catalán-Fernández, A., Comas-Forgas, R., Fagan, G., Llabrés-Bernat, A., 2011. Perception of pine trees among citizens of the Balearic islands: analysis and description of some Mistaken ideas. Appl. Environ. Educ. Commun. Int. J. 10, 31-42.

Tapias, R., Climent, J., Pardos, J., Gil, L., 2004. Life histories of Mediterranean pines. Plant Ecol. 171, 53-68.

Thanos, C.A., Daskalakou, E.N., 2000. Reproduction in Pinus Halepensis and P. Brutia. In: Ne'eman, G., Trabaud, L. (Eds.), Ecology, Biogeography and Management of Pinus Halepensis and P. Brutia Forest Ecosystems in the Mediterranean Basin. Backhuys Publishers, Leiden, pp. 79-90.

van der Kaars, S., Penny, D., Tibby, J., Fluin, J., Dam, R., Suparan, P., 2001. Late Quaternary palaeoecology, palynology and palaeolimnology of a tropical lowland swamp: Rawa Danau, West Java, Indonesia. Palaeogeogr. Palaeoclimatol. Palaeoecol. 171, 185-212.

Vernet, J.-L., Badal, E., Grau, E., 1987. L'environnement végétal de l'homme du Néolithique dans le Sud-Est de l'Espagne (Valence, Alicante), d'après l'analyse anthracologique. In: Guilaine, J., Courtin, J., Roudil, J.-L., Vernet, J.-L. (Eds.), Premières Communautés Paysannes en Méditerranée Occidentale, pp. 31-136. C.N. R.S., Paris.

Yll, E.I., Pérez-Obiol, R., Pantaleón-Cano, J., Roure, J.M., 1997. Palynological evidence for climatic change and human activity during the Holocene on Menorca (Balearic Islands), Quat. Res. 48, 339-347.

Yll, E.I., Pantaleón-Cano, J., Pérez-Obiol, R., Roure, J.M., 1999. Cambio climático y transformaciones del medio durante el Holoceno en las Islas Baleares. Saguntum PLAV, Extra-2 45-51.

Yll, R., Expósito, I., Burjachs, F., 2010. Anàlisi palinològica del jaciment arqueològic de l'Hospitalet Vell (Manacor, Mallorca). Informe 2010/006/PL. Technical report, 21 p. 